\title{
UTP - Gated Signaling Pathways of 5-HT Release from BON Cells as a Model of Human Enterochromaffin Cells
}

\author{
Andromeda Liñán-Rico ${ }^{1 t}$, Fernando Ochoa-Cortes ${ }^{1+}$, Alix Zuleta-Alarcon ${ }^{1}$, Mazin Alhaj', \\ Esmerina Tili ${ }^{1,2}$, Josh Enneking ${ }^{1}$, Alan Harzman ${ }^{3}$, Iveta Grants ${ }^{1}$, Sergio Bergese ${ }^{1}$ and \\ Fievos L. Christofi ${ }^{*}$ * \\ 1 Department of Anesthesiology, The Wexner Medical Center at The Ohio State University, Columbus, OH, United States, \\ ${ }^{2}$ Molecular Virology, Immunology and Medical Genetics, The Wexner Medical Center at The Ohio State University, \\ Columbus, $\mathrm{OH}$, United States, ${ }^{3}$ Department of Surgery, The Wexner Medical Center at The Ohio State University, \\ Columbus, $\mathrm{OH}$, United States
}

Background: Enterochromaffin cells (EC) synthesize and release 5-HT and ATP to trigger or modulate gut neural reflexes and transmit information about visceral/pain sensation. Alterations in 5-HT signaling mechanisms may contribute to the pathogenesis of IBD or IBS, but the pharmacologic or molecular mechanisms modulating $\mathrm{Ca}^{2+}$ dependent 5-HT release are not understood. Previous studies indicated that purinergic signaling via ATP and ADP is an important mechanism in modulation of $5-\mathrm{HT}$ release. However, EC cells also respond to UTP and UDP suggesting uridine triphosphate receptor and signaling pathways are involved as well. We tested the hypothesis that UTP is a regulator of $5-\mathrm{HT}$ release in human EC cells.

Methods: UTP signaling mechanisms were studied in BON cells, a human EC model, using Fluo-4/Ca ${ }^{2+}$ imaging, patch-clamp, pharmacological analysis, immunohistochemistry, western blots and $\mathrm{gPCR}$. 5-HT release was monitored in $\mathrm{BON}$ or EC isolated from human gut surgical specimens (hEC).

Results: UTP, UTP $\gamma$ S, UDP or ATP induced $\mathrm{Ca}^{2+}$ oscillations in BON. UTP evoked a biphasic concentration-dependent $\mathrm{Ca}^{2+}$ response. Cells responded in the order of UTP, ATP > UTP $\gamma S>$ UDP $>>$ MRS2768, BzATP, $\alpha, \beta$-MeATP > MRS2365, MRS2690, and NF546. Different proportions of cells activated by UTP and ATP

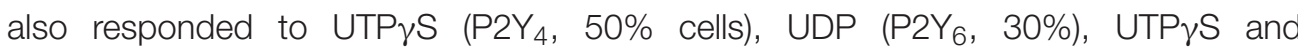
UDP $(14 \%)$ or MRS2768 (<3\%). UTP $\mathrm{Ca}^{2+}$ responses were blocked with inhibitors of PLC, IP3R, SERCA Ca ${ }^{2+}$ pump, $\mathrm{La}^{3+}$ sensitive $\mathrm{Ca}^{2+}$ channels or chelation of intracellular free $\mathrm{Ca}^{2+}$ by BAPTA/AM. Inhibitors of L-type, TRPC, ryanodine-Ca ${ }^{2+}$ pools, PI3-Kinase, PKC or SRC-Kinase had no effect. UTP stimulated voltage-sensitive $\mathrm{Ca}^{2+}$ currents $\left(\mathrm{I}_{\mathrm{Ca}}\right), V_{\mathrm{m}}$-depolarization and inhibited $\mathrm{I}_{\mathrm{K}}$ (not $\mathrm{I}_{\mathrm{A}}$ ) currents. An $\mathrm{I}_{\mathrm{Kv}} 7.2 / 7.3$ $\mathrm{K}^{+}$channel blocker XE-991 mimicked UTP-induced $\mathrm{V}_{\mathrm{m}}$-depolarization and blocked UTP-responses. XE-991 blocked $I_{K}$ and UTP caused further reduction. La ${ }^{3+}$ or PLC inhibitors blocked UTP depolarization; PKC inhibitors, thapsigargin or zero $\mathrm{Ca}^{2+}$ buffer did not. UTP stimulated 5-HT release in hEC expressing TPH1, 5-HT, P2Y $/ \mathrm{P}_{2} \mathrm{Y}_{6} \mathrm{R}$. Zero- $\mathrm{Ca}^{2+}$ buffer augmented $\mathrm{Ca}^{2+}$ responses and 5-HT release. 


\begin{abstract}
Conclusion: UTP activates a predominant $\mathrm{P}_{2} \mathrm{Y}_{4} \mathrm{R}$ pathway to trigger $\mathrm{Ca}^{2+}$ oscillations via internal $\mathrm{Ca}^{2+}$ mobilization through a PLC/IP3/IP3R/SERCA $\mathrm{Ca}^{2+}$ signaling pathway to stimulate $5-\mathrm{HT}$ release; $\mathrm{Ca}^{2+}$ influx is inhibitory. UTP-induced $\mathrm{V}_{\mathrm{m}}$-depolarization depends on PLC signaling and an unidentified $\mathrm{K}$ channel (which appears independent of $\mathrm{Ca}^{2+}$ oscillations or $\mathrm{I}_{\mathrm{ca}} \mathrm{NOCC}$ ). UTP-gated signaling pathways triggered by activation of $\mathrm{P} 2 \mathrm{Y}_{4} \mathrm{R}$ stimulate $5-\mathrm{HT}$ release.
\end{abstract}

Keywords: EC cells, calcium, purinergic signaling, UTP, 5-HT, $\mathrm{P}_{2} \mathrm{Y}_{4}, \mathrm{P}_{2} \mathrm{Y}_{6}$

\section{INTRODUCTION}

Enterochromaffin cells (EC) synthesize and release 5-HT, ATP and other mediators involved in gut neural reflexes and transmission of information about visceral/pain sensation (Kellum et al., 1999; Kim et al., 2001a; Raybould et al., 2004; Cooke and Christofi, 2006; Christofi, 2008). While EC cells release large quantities of endogenous 5-HT and exogenous 5-HT does stimulate gut motility, the mucosa and release of 5-HT from the mucosa are not required for in vitro peristalsis in the guineapig distal colon (Spencer et al., 2011) or in vivo intestinal transit of content (Yadav et al., 2010). However, abnormal regulation of 5-HT occurs in gastrointestinal disorders and inflammatory bowel diseases (IBD), where 5-HT signaling may represent a key mechanism in the pathogenesis of intestinal inflammation (Mawe and Hoffman, 2013; Liñán-Rico et al., 2016). Emerging evidence suggests that alterations in 5-HT release or handling mechanisms may contribute to IBD, Irritable Bowel Syndrome (IBS) and the diarrhea associated with bacterial toxin enterocolitis. Abnormal 5-HT signaling has also been implicated in diverticular disease, celiac disease, and colorectal cancer (Crowell, 2004; Galligan, 2004; Gershon, 2004; Kordasti et al., 2004; O'Hara et al., 2004; Manocha and Khan, 2012). Yet, the basic mechanisms regulating 5-HT release in human EC cells (hEC) are poorly understood. To understand the basis of these gastrointestinal disorders, it is necessary first to better understand how 5-HT release is regulated at cellular and molecular levels.

Enterochromaffin cells have chemo- and mechanosensitive elements that detect changes in force or contents of the intestinal lumen during peristalsis (Kim et al., 2001a; Christofi, 2008), the basic reflex underlying all motility patterns. The human BON cell line is a useful model to study chemosensation and mechanosensation, receptor regulation, post-receptor signaling pathways and physiological regulation of 5-HT release (Kim et al., 2001a,b, 2007; Cooke et al., 2003; Christofi et al., 2004a; Germano et al., 2009; Liñán-Rico et al., 2013).

Recent studies have employed freshly isolated hEC after acute isolation (Dammen et al., 2013) or in short term culture (Raghupathi et al., 2013) to study 5-HT release. However, the

Abbreviations: $\left[\mathrm{Ca}^{2+}\right]_{\mathrm{i}}$, intracellular free calcium levels; $\mathrm{CP}$, control immunogenic peptide; CRAC, calcium release activated channels; EC, enterochromaffin cell; GI, gastrointestinal; GPCR, G protein coupled receptor; hEC, human enterochromaffin cell; $\mathrm{I}_{\mathrm{A}}$, type A voltage dependent potassium currents; $\mathrm{I}_{\mathrm{ca} 2+}$, Voltage dependent calcium currents; $\mathrm{I}_{\mathrm{K}}$, type $\mathrm{K}$ voltage dependent potassium currents; $\mathrm{K}_{\mathrm{v}}$, potassium currents; NSCC, non-selective cation currents; Ri, input resistance; RuRed, ruthenium red; SOCE, store operated $\mathrm{Ca}^{2+}$ entry; TPC, twopore channel; VOCC, voltage operated calcium channel. gold-standard for purinergic signaling studies remains the BON (EC) cell line since most of our knowledge of ATP (nucleotide) regulation of EC/5-HT signaling comes from these cells. A stable human cell line that is well characterized is appropriate for detailed mechanistic studies. Native hEC isolated from surgical specimens can be used to confirm key observations.

Purine receptors are broadly divided into nucleoside (P1, for adenosine) and nucleotide receptors (P2, for ATP, ADP, UTP and $\mathrm{UDP}) . \mathrm{P} 2$ is subdivided into $\mathrm{P} 2 \mathrm{X}$ channel receptor $\left(\mathrm{P}_{2} \mathrm{X}_{1-7}\right)$ and G-protein coupled receptor $\left(\mathrm{P}_{2} \mathrm{Y}_{1,2,4,6,11-14}\right)$ families (Khakh et al., 2001; Kügelgen, 2006). Purinergic transmission occurs in the human enteric nervous system (Wunderlich et al., 2008; Liñán-Rico et al., 2015) and is known to act at all levels of gut secretory and motility reflexes (Burnstock, 2008; Christofi, 2008). Purinergic receptors are sensitive to mucosal inflammation and are emerging as potential novel therapeutic targets for GI diseases and disorders (Ochoa-Cortes et al., 2014).

Of particular interest is the role of purinergic signaling in EC cells. We could show that mechanical stimulation of the mucosa releases ATP that is required for triggering secretomotor reflexes (Christofi et al., 2004b; Cooke et al., 2004). Adenosine, a metabolite of ATP, is an important autoregulatory modulator of $\mathrm{Ca}^{2+}$-dependent 5-HT release (Christofi et al., 2004a). Our previous studies showed that purinergic signaling is an important mechanism in the modulation of 5-HT release. ATP is a critical determinant of mechanosensation and 5-HT release via autocrine activation of slow stimulatory $\mathrm{P}_{2} \mathrm{Y}_{1}$, inhibitory $\mathrm{P} 2 \mathrm{Y}_{12}$ purinergic pathways, and fast ATPgated $\mathrm{P}_{2} \mathrm{X}_{3}$-channels. Down-regulation of $\mathrm{P}_{2} \mathrm{X}_{3}$-channels (or alterations in $\mathrm{A}_{2 B}$ ) is postulated to mediate abnormal 5-HT signaling (Liñán-Rico et al., 2013). The cognate ligands for these receptors are ATP and adenosine-5'-diphosphate (ADP). However, it is evident from our early observations that UTP and UDP, uridine nucleotides, can elicit $\mathrm{Ca}^{2+}$ oscillations in human BON (EC) cells. This suggests that a uridine nucleotide receptor is involved in $\mathrm{Ca}^{2+}$ oscillations leading to serotonin release in hEC. Candidate receptors are $\mathrm{P}_{2} \mathrm{Y}_{2}, \mathrm{P}_{2} \mathrm{Y}_{4}$ and $\mathrm{P} 2 \mathrm{Y}_{6}$ receptors.

We sought to test the novel hypothesis that UTP is a regulator of $\mathrm{Ca}^{2+}$ dependent 5-HT release in hEC by activating P2Y uridine nucleotide receptors. In light of the potential for targeting such receptors in GI diseases, we thought it would be important to identify the receptor(s), post-receptor, ionic and molecular signaling mechanisms linked to $\mathrm{Ca}^{2+}$ oscillations and 5-HT release. Collectively, our findings indicate that several uridine 
nucleotide receptors are linked to $\mathrm{Ca}^{2+}$ oscillations, membrane depolarization, modulation of ionic currents and 5-HT release. Post-receptor signaling mechanisms include a $\mathrm{GPCR} / \mathrm{Gq} / \mathrm{IP}_{3}$ IP3R - $\mathrm{Ca}^{2+}$ signaling pathway, $\mathrm{Ca}^{2+}$ influx, SERCA, $\mathrm{I}_{\mathrm{Kv}}$ 7.1,7.2/7.3 and VOCC $\left(\mathrm{I}_{\mathrm{ca}}\right)$. Data support the hypothesis that UTP activates $\mathrm{P}_{2} \mathrm{Y}_{4}$ and $\mathrm{P} 2 \mathrm{Y}_{6}$ receptors to modulate a $\mathrm{GPCR} / \mathrm{Gq} / \mathrm{IP}_{3}$ IP3R -SERCA Ca ${ }^{2+}$ signaling pathway leading to 5-HT release. Effect of UTP on membrane depolarization was not linked to a $\mathrm{Ca}^{2+}$ dependent 5-HT release.

\section{MATERIALS AND METHODS}

\section{IRB Approval}

Studies conducted in hEC were carried out in accordance with the Declaration of Helsinki and approved by an Institutional Review Board (IRB) ethics committee at The Ohio State University. The protocol was \# 2012H0231. Patient consent was obtained for each human subject and surgical tissue that is otherwise discarded by pathology was used to isolate hEC for studies on 5-HT release, or western blot analysis in human mucosa for P2Y receptors. Eight Roux-en-Y surgical specimens and 3 colonic specimens were collected for our studies. Colonic surgical specimens were obtained from patients undergoing a left colectomy for polyps/adenomas from the descending colon.

\section{Chemicals}

Stock solutions of all drugs were prepared as per vendor indications, aliquoted and kept at $-20^{\circ} \mathrm{C}$ ( or $-80^{\circ} \mathrm{C}$ ) until used. ATP, UTP, UDP were from Sigma-Aldrich (St. Louis, MO, United States) and UTP $\gamma S$, thapsigargin, U73122, U73343, GF109203X, $\alpha, \beta$-MeATP, MRS compounds and XE-991 dihydrochloride were from TOCRIS Bioscience (Bristol, United Kingdom). Poly-Dlysine, Laminin, HBSS, DMEM: F12 medium were purchased from Life Science Technologies (Carlsbad, CA, United States). All other substances were purchased from Sigma-Aldrich (St. Louis, MO, United States).

\section{Cell Culture}

\section{Bon Cell Culture}

BON cells were a gift from C.M. Townsend Jr (University of Texas, Galveston, TX, United States). Clone No. 7 was highly enriched with 5-HT. The cells were seeded on No. 0 cover slips (MatTek, Corp., Ashland, MA, United States) at a density of $5 \times 10^{4}$ cells for calcium experiments and $5 \times 10^{5}$ cells per well in 24-well culture plates (Corning-Costar Corp., Corning, NY, United States) for 5-HT release experiments. For patch clamp experiments cells were plated $\left(6 \times 10^{3}\right)$ as droplets onto cover-slips pre-coated with Laminin/poly-D-Lysine $(20 \mu \mathrm{g} / \mathrm{ml}$ each) and left to settle $2 \mathrm{~h}$ at $37^{\circ} \mathrm{C}$. Cells were grown in Dulbecco-modified Eagle medium-nutrient mixture F-12 (1:1), supplemented with $10 \%$ fetal calf serum, $100 \mathrm{IU} / \mathrm{mL}$ penicillin, and $100 \mathrm{mg} / \mathrm{mL}$ streptomycin (Life Technologies, Grand Island, NY, United States). Cells were grown in a humidified atmosphere of $95 \%$ air and $5 \% \mathrm{CO}_{2}$ at $37^{\circ} \mathrm{C}$ until reaching $70-90 \%$ confluence for calcium experiments (4-8 days after being seeded) and $48 \mathrm{~h}$ for 5-HT release. Passage numbers were from 29 to 66 .

\section{Human EC Culture}

Human EC cells were isolated from mucosa of intestinal surgical specimens as described by Raghupathi et al. (2013). Mucosa was carefully scraped with bent forceps and collected in a $50 \mathrm{ml}$ tube. The cells were washed with physiological buffer containing (in $\mathrm{mM}$ ): $140 \mathrm{NaCl}, 5 \mathrm{KCl}, 2 \mathrm{CaCl}_{2}, 1 \mathrm{MgCl}_{2}$, 10 HEPES, 5 D-glucose, $\mathrm{pH}$ 7.4. After $10 \mathrm{~min}$ centrifugation at $1000 \mathrm{rmp}\left(4^{\circ} \mathrm{C}\right)$ the tissue was placed in digestion buffer containing $0.05 \%$ Trypsin-EDTA and $1 \mathrm{mg} / \mathrm{ml}$ collagenase A made in physiological buffer. Digestion was done at $37^{\circ} \mathrm{C}$ for 30 min with continuous agitation and triturating the cells every 10 min using a $5 \mathrm{ml}$ pipette to pass the cells 20 times back and forth until no large pieces were visible. Enzymatic reaction was stopped by adding equal volume of DMEM with $10 \%$ FBS, $1 \%$ glutamine and $1 \%$ penicillin/streptomycin. Cell suspension was filtered through 100, 70 and $40 \mu \mathrm{m}$ cell strainers into a $50 \mathrm{ml}$ tube and centrifuged at $800 \times g$ for $5 \mathrm{~min}$. Pellet was re-suspended in $4 \mathrm{ml}$ of growth medium and layer onto a Percoll density gradient prepared in $\mathrm{NaCl}$. EC cells were harvested at a density of $1.07 \mathrm{~g} / \mathrm{L}$ after centrifugation at $1,100 \times g$ for $15 \mathrm{~min}$. Cells were collected using a transfer pipette with a thin tip and rinsed with fresh media. Cells were re-suspended in $1 \mathrm{ml}$ of complete DMEM $+10 \%$ FBS and $1.2 \mathrm{mM}$ insulin, $68.7 \mathrm{nM}$ transferrin, and $38.7 \mathrm{nM}$ sodium selenite.

\section{$\mathrm{Ca}^{2+}$ Imaging}

BON cells were loaded with $2 \mu \mathrm{M}$ Fluo-4/AM (Molecular Probes, Eugene, OR, United States) in DMEM for $20 \mathrm{~min}$ in a 95\% air and $5 \% \mathrm{CO}_{2}$ incubator at $37^{\circ} \mathrm{C}$. The $\mathrm{Ca}^{2+}$ response was monitored using a modified-Zeiss LSCM 410/REN laser scanning confocal imaging system. Cells were perfused at $6 \mathrm{ml} / \mathrm{min}$ with oxygenated Krebs solution (Table 1). A "solution inline heater" (Warner Instruments, Inc., Hamden, CT, United States) was used to maintain the perfusion temperature at $36.5 \pm 0.5^{\circ} \mathrm{C}$. Cells were imaged through a $40 \times$ oil immersion apofluor objective (numerical aperture 1.3, working distance $=170 \mu \mathrm{m}$ ). $\mathrm{Ca}^{2+}$ imaging was carried out using an Ar-Kr laser to excite the cells at $488 \mathrm{~nm}$, and fluorescence emissions were passed through a FT510 dichroic mirror and collected through a photomultiplier tube equipped with a BP 505-550 filter, positioned in front of pinhole and light path. Time-series analysis of $\left[\mathrm{Ca}^{2+}\right]_{i}$ was done at 1 -s intervals.

Some experiments were performed using the Nikon FN1 Electrophysiology Microscope imaging system equipped with an Andor iXON Ultra camera (11 bit and 16 bit) for real-time calcium imaging; the camera is able to capture images at 55 frames/s. The system also includes the following components: A CFI Fluor $40 \times$ Water immersion objective lens (NA 0.8 WD $2 \mathrm{~mm}$ ) was used with a long working distance achromatic condenser: NA 0.56 with adjustable diaphragm graduated in NA working distance $9.6 \mathrm{~mm}$ and a 6 place turret with fiber based light source (D-FI Universal EPI-Fluor Illuminator), Fluo-4 cube and NIS Elements Analysis 4.13 (Advanced calcium imaging analysis software).

Cells were perfused at $2 \mathrm{ml} / \mathrm{min}$ using a peristaltic pump, and drugs were applied by perfusion for 2 min (unless otherwise 
TABLE 1 | Standard solutions composition.

\begin{tabular}{|c|c|c|c|c|c|c|}
\hline Reactive & \multicolumn{6}{|c|}{ Standard solutions (mM) } \\
\hline $\mathrm{NaH} 2 \mathrm{PO} 4$ & 1.35 & & & & & \\
\hline $\mathrm{NaCl}$ & 120 & 130 & & & & \\
\hline Glucose & 12.7 & 5 & & 5 & & 1 \\
\hline $\mathrm{MgCl}_{2}$ & 1.35 & 1 & 1 & 2 & 4 & 1 \\
\hline HEPES & & 10 & 10 & 10 & 10 & 2 \\
\hline K-Gluconate & & & 110 & & & \\
\hline NMDG & & & & 95 & & 140 \\
\hline TEA-Cl & & & & 35 & & \\
\hline ATP-Mg & & & & & 4 & \\
\hline GTP-Na & & & & & $0.3-0.5$ & \\
\hline $\mathrm{CdCl}_{2}$ & & & & & & 0.1 \\
\hline $\mathrm{pH}$ & & 7.3-7.4 NaOH & $7.25 \mathrm{KOH}$ & $7.3-7.4 \mathrm{HCl}$ & $7.25 \mathrm{CsOH}$ & $7.3-7.4 \mathrm{HCl}$ \\
\hline
\end{tabular}

specified). The lag between drug application and response is due to time lag for drug to reach the desired concentration in the chamber at the perfusion rate and volume of the chamber $(\sim 1.5 \mathrm{ml})$.

\section{5-HT Release}

BON cells were washed with a Ringer-like solution: $120 \mathrm{mM}$ $\mathrm{NaCl}, 6 \mathrm{mM} \mathrm{CsCl}, 1 \mathrm{mM} \mathrm{MgCl} 2,10 \mathrm{mM}$ glucose, and $10 \mathrm{mM}$ HEPES-Na and $1.5 \mathrm{mM} \mathrm{CaCl}_{2}$ (pH 7.4) containing $0.1 \%$ BSA. For $0 \mathrm{Ca}^{2+}$ Ringer-like buffer, extracellular calcium was omitted and $0.5 \mathrm{mM}$ EGTA was added. After pre-incubation for $30 \mathrm{~min}$ at $37^{\circ} \mathrm{C}$, the buffer was removed and replaced with $0.6 \mathrm{ml}$ Ringerlike solution that contained $10^{-5} \mathrm{M}$ of alaproclate (5-HT uptake inhibitor) and pargyline (monoamine oxidase inhibitor) and the drug of interest (ATP or UTP). Cells were incubated for $30 \mathrm{~min}$ at $37^{\circ} \mathrm{C}$ and after that, $0.5 \mathrm{ml}$ of the assay buffer was collected in a $1.5 \mathrm{ml}$ tube containing 1\% stabilizer (LDN, Nordhorn, Germany) and frozen at $-80^{\circ} \mathrm{C}$ until the 5-HT assay was performed.

For 5-HT release in human EC cells, $1 \times 10^{5}$ cells were centrifuged at $8 \times \mathrm{g}$ for $10 \mathrm{~min} / 4^{\circ} \mathrm{C}$, medium was removed and replaced with $0.2 \mathrm{ml} \mathrm{EBSS} \mathrm{buffer} \mathrm{containing} 1.8 \mathrm{mM} \mathrm{CaCl}_{2}$, $0.8 \mathrm{mM} \mathrm{MgSO}_{4}-7 \mathrm{H}_{2} \mathrm{O}, 5.3 \mathrm{mM} \mathrm{KCL}, 26 \mathrm{mM} \mathrm{NaHCO}_{3}, 117 \mathrm{mM}$ $\mathrm{NaCl}, 1 \mathrm{mM} \mathrm{NaH}{ }_{2} \mathrm{PO}_{4}-\mathrm{H}_{2} \mathrm{O}$ and $5.5 \mathrm{mM}$ D-Glucose with $0.1 \%$ BSA, $10^{-5} \mathrm{M}$ of alaproclate and pargyline. Cells were allowed to equilibrate for $2 \mathrm{~h}$ at $37^{\circ} \mathrm{C}$. After incubation, the drugs were added (final volume of $204 \mu \mathrm{l}$ ) and cells were incubated for $30 \mathrm{~min}$ at $37^{\circ} \mathrm{C}$. Cells were centrifuged $8 \times g$ for $5 \mathrm{~min} / 4^{\circ} \mathrm{C}$ and the supernatant was collected in a $1.5 \mathrm{ml}$ tube containing $1 \%$ stabilizer (LDN, Nordhorn, Germany) and saved at $-80^{\circ}$ C. 5-HT release was measured by enzyme immunoassay using an ELISA kit (LDN, Nordhorn, Germany) according to the manufacturer's instructions. The absorbance was measured at $450 \mathrm{~nm}$ and 5-HT concentration was determined from a standard curve.

\section{Western Blot}

Cells were washed with cold PBS and lysed in lysis buffer containing: $50 \mathrm{mM}$ Tris- $\mathrm{HCl}, \mathrm{pH} 7.4,150 \mathrm{mM} \mathrm{NaCl}, 1 \mathrm{mM}$ $\mathrm{Na}_{3} \mathrm{VO}_{4}, 1 \mathrm{mM} \mathrm{NaF}, 0.25 \%$ sodium deoxycholate, $1 \% \mathrm{NP} 40$, $1 \mathrm{mM}$ EGTA, $1 \mathrm{mM}$ PMSF and protein inhibitor cocktail from Sigma-Aldrich (P8340). Protein concentration was calculated with Bradford assay (Bio-Rad, Hercules, CA, United States). Eighty microgram of cell lysate (or $20 \mu \mathrm{g}$ for human mucosa) was denatured at $90^{\circ} \mathrm{C}$ for $10 \mathrm{~min}$ in $1: 1$ volume of $2 \mathrm{X}$ Laemmli sample buffer (Bio-Rad, United States) and $8 \%$ 2 -mercaptoethanol. Protein samples were separated on a $10 \%$ SDS-PAGE gel and transferred to a PVDF membrane (Bio-Rad, Hercules, CA, United States). After blocking in 5\% non-fat dry milk buffer, the membranes were incubated overnight at $4^{\circ} \mathrm{C}$ with rabbit anti-P2Y (1:200; Alomone, Jerusalem, Israel, APR010), anti-P2Y 4 (1:800; Alomone, APR-006), anti-P2Y 6 (1:600; Alomone, APR-011), TPH1 (1:1000; Novus Biologicals, Littleton, CO, United States, NB110-57629) or anti-mouse $\beta$-actin (1:1000; Santa Cruz Biotech, Dallas, TX, United States, sc-47778) in blocking solution. Membranes were washed and incubated with the HPR-conjugated secondary anti-rabbit or anti-mouse antibody (1:1000; Cell Signaling Technology, Danvers, MA, United States).

\section{Immunochemical Labeling}

Cells were fixed in 4\% PFA for 20 min and washed with PBS. Cells were blocked for 30 min with 10\% normal donkey serum, 0.5\% Triton X-100 in PBS. Primary antibody incubation was done at 
1:50 dilution for rabbit anti-P2Y $\mathrm{Y}_{4}$ (Alomone, Jerusalem, Israel) and 1:20 dilution for mouse anti-5-HT (Dako, Carpinteria, CA, United States, M0758). After washing, incubation with Alexafluor 488 or 568 secondary antibody at 1:400 dilution (Life Tech, Cedarhurst, NY, United States) was done for $30 \mathrm{~min}$ at room temperature, protected from light.

\section{RNA Isolation and Quantitative Real-Time PCR (qRT-PCR)}

RNAs were extracted using TRIzol (Invitrogen, Buffalo, NY, United States). They were subsequently subjected to DNase digestion (Turbo-DNase Ambion - Life Technologies, Grand Island, NY, United States). Two micrograms per sample RNA was used to prepare the cDNA utilizing High-Capacity cDNA Reverse Transcription Kit (Random priming) with RNase Inhibitor (Life Technologies, Grand Island, NY, United States). Quantitative RT-PCRs were performed using the TaqMan Gene Expression Assays from Applied Biosystems - Life Technologies (Grand Island, NY, United States): Hs00267404_s1 for P2Y 4 and Hs00366312_m1 for P2Y 6 . Quantitative RT-PCRs (100 ng of cDNA per $20-\mu \mathrm{L}$ amplification reaction) were performed in triplicates. Gene expression levels were quantified using the ABI Prism 7900HT Sequence detection system (Applied Biosystems). Relative expression was calculated using the comparative $C_{t}$ method. Values were normalized using OAZ1 Gene Expression assay (TaqMan assay Hs00427923_m1).

\section{Patch-Clamp Experiments}

Recordings were made from BON cells after 4 days of culture on a SliceScope Pro upright microscope (Scientifica-Olympus, Uckfield, United Kingdom). Membrane potential was assessed using perforated patch with amphotericin B, $300 \mu \mathrm{g} / \mathrm{mL}$. Thin walled glass-capillaries (Warner Instruments) were used in electrode fabrication with a horizontal micropipette puller P97 (Sutter Instrument Co., Novato, CA, United States). Pipette resistance was 2-5 $\mathrm{M} \Omega$ when immersed in bath solution. Cell signals were amplified and digitized by using Multiclamp 700B amplifier and Digidata 1440A converter, and stored using pClamp 10.3 software (Molecular Devices, Sunnyvale, CA, United States).

Experiments were performed at $34 \pm 0.5^{\circ} \mathrm{C}$ and temperature was maintained using a single channel TC-324B temperature controller (Harvard Apparatus, Holliston, MA, United States). During experiments, cells were continuously perfused with bath external solution to an approximate rate of $2 \mathrm{~mL} / \mathrm{min}$ with and without required testing compounds; UTP was applied for 2 to $3 \mathrm{~min}$ while changes in resting membrane potential were recorded. Other treatments or inhibitors were pre-incubated as indicated in specific experiments. Changes in $\mathrm{Ri}$ were assessed by applying hyperpolarizing current pulses of $-10 \mathrm{mV}$ at a frequency of $6 \mathrm{~Hz}$. When necessary, cells were previously incubated with antagonists as required. Standard solutions are described in Table $\mathbf{1 .}$

In current clamp experiments a liquid junction potential was calculated to be $-10.8 \mathrm{mV}$, and was corrected for analyzing the data. $\mathrm{I}_{\mathrm{Ca}^{2+}}$ were recorded using whole cell patch-clamp and series resistance was compensated in every cell at least $70 \%$; cells with a holding leak-current larger than $-50 \mathrm{pA}$ were rejected and no further leak correction was made. Once the Giga seal was formed and membrane ruptured in normal bath solution, cells were bathed 10 min with $\mathrm{Cs}^{+} / \mathrm{Ba}^{2+}$ solution to allow a complete exchange of solutions and internal medium dialysis. $\mathrm{Ba}^{2+}$ current was then assessed through voltage-operated $\mathrm{Ca}^{2+}$ channels (VOCC). Currents were stimulated giving $100 \mathrm{~ms}$ voltage steps from -70 to $40 \mathrm{mV}$ with increments of $10 \mathrm{mV}$, every $5 \mathrm{~s}$, from a holding potential $\left(\mathrm{V}_{\mathrm{h}}\right)$ of $-80 \mathrm{mV}$ and recorded at a sampling rate of $10 \mathrm{kHz}$ and low pass filtered to $1 \mathrm{kHz}$. All currents were expressed as current density $(\mathrm{pA} / \mathrm{pF})$ and normalized to cell capacitance. Currents were changed to conductance to generate activation curves, plotted as $G / G_{\max }$ and fitted with a Boltzmann equation.

For voltage-dependent potassium currents $\left(\mathrm{K}_{\mathrm{V}}\right)$, normal pipette solution was used. Type $A\left(I_{A}\right)$ and type $K\left(I_{K}\right)$ voltage dependent potassium currents were separated by their inactivation properties. Total potassium currents were evoked with $500 \mathrm{~ms}$ voltage pulses ranging from -90 to $+50 \mathrm{mV}$ from a $\mathrm{V}_{\mathrm{h}}$ of $-100 \mathrm{mV}\left(\mathrm{I}_{\mathrm{Tot}}\right)$ and $-40 \mathrm{mV}\left(\mathrm{I}_{\mathrm{K}}\right)$. $\mathrm{I}_{\mathrm{K}}$ peak amplitude was measured at the end of the traces obtained in each voltage step and $\mathrm{I}_{\mathrm{A}}$ was at the maximum peak (start of pulse) produced after withdrawing $\mathrm{I}_{\mathrm{K}}$ from $\mathrm{I}_{\mathrm{Tot}}$. Currents were normalized to cell capacitance and are shown as current density $(\mathrm{pA} / \mathrm{pF})$ after being fitted with a Boltzmann equation.

\section{Experimental Protocols}

(1) We tested the effect of UTP, ATP and agonists with selectivity for $\mathrm{P}_{2} \mathrm{Y}_{1}$ (MRS2365), $\mathrm{P}_{2} \mathrm{Y}_{2}$ (MRS2768), $\mathrm{P} 2 \mathrm{Y}_{2 / 4}$ (UTP $\gamma$ S), $\mathrm{P}_{2} \mathrm{Y}_{6}$ (UDP), P2Y 11 (NF546), P2Y 14 (MRS2690), $\mathrm{P}_{2} \mathrm{X}_{7}$ (BzATP) and $\mathrm{P}_{2 \mathrm{X}}, 2 / 3,3\left(\alpha, \beta\right.$-MeATP) on $\mathrm{Ca}^{2+}$ responses. Drug concentrations were selected according to reported selectivity and $\mathrm{EC}_{50} \mathrm{~s}$ in human cells (Abbracchio et al., 2006; Brunschweiger and Müller, 2006; Kügelgen and Bonn, 2008).

(2) A concentration-dependent $\mathrm{Ca}^{2+}$ response to UTP was determined in the range of $1 \mathrm{nM}$ to $5 \mathrm{mM}$. Different concentrations of UTP were applied at $10 \mathrm{~min}$ intervals to allow sufficient time to washout and fully recover from the drug (as determined in preliminary experiments) (Brinson and Harden, 2001).

(3) Using this protocol, 3-4 different concentrations of drug could be applied to each cell to construct a full dose-response curve. It is possible to demonstrate a concentration-dependent effect in the same cell. However, it is not possible to determine the entire concentration response curve in each cell with reproducibility (i.e., possibly due to cell fatigue, desensitization, prolonged exposure to light to monitor $\mathrm{Ca}^{2+}$ responses, etc.). Therefore, analysis allowed determination of apparent $\mathrm{EC}_{50} \mathrm{~s}$, since a full concentration response curve could not be obtained in the same cell.

(4) We determined the profile of $\mathrm{Ca}^{2+}$ activity in response to consecutive applications of selective uridine nucleotide 
agonists (i.e., MRS2768, UTP $\gamma S$, UDP) to identify the proportions of UTP-responsive cells with functional $\mathrm{P}_{2} \mathrm{Y}_{2} \mathrm{R}, \mathrm{P} 2 \mathrm{Y}_{4} \mathrm{R}$ and $\mathrm{P} 2 \mathrm{Y}_{6} \mathrm{R}$ receptors.

(5) Determined the expression of uridine phosphate receptors by western blot, immunofluorescent labeling and/or qPCR analysis for selected receptors in BON, isolated human EC cells from intestinal surgical specimens, human mucosa and HT-29 cells.

(6) UTP effects of 5-HT release were analyzed in BON and human EC (hEC) cells.

(7) $\mathrm{Ca}^{2+}$ signaling pathways linked to UTP were determined using pharmacological inhibitors, receptor or channel blockers. Drugs were pre-incubated for 10-30 min depending on the drug. Paired data was obtained for all treatments (unless otherwise noted).

(8) Determined the effects of UTP on $V_{m}$ depolarization and voltage-operated $\mathrm{Ca}^{2+}$ channels (VOCCs) and voltageactivated potassium channels $\left(\mathrm{K}_{\mathrm{v}}\right.$ channels) by evaluating (i) The effect of UTP induced rise in $\left[\mathrm{Ca}^{2+}\right]_{i}$ on $\mathrm{V}_{\mathrm{m}}$ Depolarization of the EC cells. (ii) Determined if UTP activates voltage-operated $\mathrm{Ca}^{2+}$ channels (VOCCs) and induces $\mathrm{I}_{\mathrm{ca}}$ currents in EC cells. (iii) Determined if UTP modulation of voltage-activated potassium currents $\left(\mathrm{K}_{\mathrm{V}}\right.$ currents: $\mathrm{I}_{\mathrm{K}}$ and $\mathrm{I}_{\mathrm{A}}$ type currents) are involved in the depolarization of EC cells.

\section{Statistical Analysis}

Statistical analysis of data was performed in Graphpad Prism 6 (La Jolla, CA, United States). Paired, unpaired $t$-test, Fisher exact test and two ways ANOVA with Bonferroni post-tests were used when appropriate. All data are expressed as mean \pm SEM. A $p<0.05$ is considered significant.

\section{RESULTS}

\section{Pharmacology of Uridine Nucleotides in BON}

In the first series of experiments, we characterized the functional uridine nucleotide receptor(s) activated by the cognate ligand UTP in BON cells. The pharmacological effects of various purinergic agonists were evaluated in inducing $\mathrm{Ca}^{2+}$ responses in BON. With the exception of UTP, a suitable concentration of each selective agonist was used to evaluate activity at different receptors (Wihlborg et al., 2003; Jacobson et al., 2009; Jacobson and Linden, 2011). Data for agonists were normalized as a $\%$ of UTP (or ATP) responsive cells (Figure 1A). The same cells responded to UTP and ATP, and these agonists caused similar responses (Supplementary Figure 1). A subset of UTP/ATP responsive cells displayed UTP $\gamma \mathrm{S}$ responses and fewer cells responded to UDP. MRS2768 was virtually ineffective and it only rarely gave a response (Figure 1A).

UTP $\left(\mathrm{P} 2 \mathrm{Y}_{2,4,6}\right), \mathrm{UTP} \gamma \mathrm{S}\left(\mathrm{P} 2 \mathrm{Y}_{2,4}\right)$, UDP $\left(\mathrm{P}_{2} \mathrm{Y}_{6}\right)$ and ATP could evoke a single monophasic $\mathrm{Ca}^{2+}$ transient, or more often caused $\mathrm{Ca}^{2+}$ oscillations (Figures 1B,C,F,G). The $\mathrm{P}_{2} \mathrm{Y}_{2}$ agonist MRS2768 could only evoke a monophasic $\mathrm{Ca}^{2+}$ transient in a tiny subset of cells (Figure 1D). Agonists that did not evoke a $\mathrm{Ca}^{2+}$ response include a $\mathrm{P}_{14} \mathrm{Y}_{14}$ agonist MRS2690, NF546 $\left(\mathrm{P} 2 \mathrm{Y}_{11}\right)$ and MRS2365 (P2Y $\mathrm{Y}_{1}$ Figure 1E). BzATP and $\alpha, \beta$ MeATP (P2X agonists) caused $\mathrm{Ca}^{2+}$ responses in less than $10 \%$ of UTP responsive cells (not shown). The percentage of the cell population with a $\mathrm{Ca}^{2+}$ response to agonists followed the order of those responding to UTP (and ATP) alone ( $\sim 50 \%$ cells $)>\mathrm{UTP} \gamma \mathrm{S}$ (and UTP, 26\%; P2Y 4 ) > UTP $\gamma$ S/UDP (and UTP, 14\%; P2Y $\mathrm{P}_{2} \mathrm{Y}_{6}$ ) > UDP (and UTP, 9\%; P2Y 6 ) > MRS2768 (and UTP, 3\%; $\left.\mathrm{P}_{2} \mathrm{Y}_{2}\right)=\operatorname{BzATP}\left(\mathrm{P}_{2} \mathrm{X}_{7}\right)=\alpha, \beta-\operatorname{MeATP}\left(\mathrm{P}_{2} \mathrm{X}_{1,2 / 3,3}\right)>\mathrm{MRS} 2365$ $\left(\mathrm{P}_{1} \mathrm{Y}_{1}\right), \mathrm{MRS}_{2690}\left(\mathrm{P} 2 \mathrm{Y}_{14}\right), \mathrm{NF}_{46}\left(\mathrm{P}_{11},<1 \%\right.$ each). Examples of pseudocolor images of $\mathrm{Ca}^{2+}$ responses to UTP $\gamma \mathrm{S}$ are shown in Figures 1I,J compared to Basal (control) in Figure $\mathbf{1 H}$.

Further pharmacological analysis tested whether monophasic and oscillatory responses are mediated by different receptors. In these experiments, only one drug at a time was tested in each cell culture. To do this we analyzed the pharmacological profile of selective agonists for oscillations (Figure 2A), monophasic responses (Figure 2B) and made comparisons between the profile of agonists between oscillations and monophasic responses (Figure 2C). Using Poisson regression analysis for numbers of cells/field responding to each agonist, the response profile for oscillations is UTP $>$ UTP $\gamma \mathrm{S}=\mathrm{ATP}>>\mathrm{UDP}>\mathrm{BzATP}>$ $\alpha, \beta$-MeATP, MRS2768, NF546. Supplementary Table 1 summarizes information on selectivity of each agonist, drug concentrations used, and responsive cells to each agonist [ATP, $100 \mu \mathrm{M}$; $\alpha, \beta$-MeATP, $10 \mu \mathrm{M} / 30 \mu \mathrm{M}$; BzATP, $\mu \mathrm{M} / 300 \mu \mathrm{M}$; UTP $\gamma \mathrm{S}, 30 \mu \mathrm{M}$; UDP, $100 \mu \mathrm{M}$; MRS2768, $10 \mu \mathrm{M}$; NF546, $30 \mu \mathrm{M}$; MRS2365, $1 \mu \mathrm{M} / 5 \mu \mathrm{M} ; \mathrm{MRS} 2690$, $0.5 \mu \mathrm{M}]$. For monophasic responses, the agonist response profile is $\mathrm{UTP}>>\mathrm{UTP} \gamma \mathrm{S}=\mathrm{ATP}=\mathrm{UDP}>\alpha, \beta$-MeATP $>$ BzATP $=$ MRS2768. Direct comparisons between oscillations and monophasic responses for each agonist indicates that significant differences exist for UTP $\gamma \mathrm{S}$, ATP (more cells with oscillations) and $\alpha, \beta$-MeATP (more cells with monophasic responses).

In a separate set of experiments, we further explored the relative distribution of functional $\mathrm{P} 2 \mathrm{Y}_{2}, \mathrm{P}_{2} \mathrm{Y}_{4}$ and $\mathrm{P} 2 \mathrm{Y}_{6}$ receptors on $\mathrm{BON}$ cells in experiments where we sequentially tested the effects of (1) MRS2768 (P2Y $)$ followed by UTP (MRS2768 $\rightarrow$ UTP), (2) UDP $\rightarrow$ UTP, and (3) UTP $\gamma S \rightarrow$ UTP. Data is summarized in Figure 3. Very few $(<10 \%)$ UTP responsive cells had MRS2768 responses, and responses were monophasic only (Figure 3A). UTP causes both oscillations and monophasic responses. A small subset of UTP-responsive cells had UDP responses (both types), but most were monophasic responses, suggesting most oscillations were in response to $\mathrm{P}_{2} \mathrm{Y}_{4}$ receptor activation (Figure 3B). However, different subsets of cells responded to UTP $\gamma$ S/UTP with oscillations, UTP alone with oscillations, UTP alone with monophasic responses, UTP $\gamma S$ with monophasic/UTP with oscillations, UTP $\gamma$ S/UTP with monophasic responses (Figure 3C).

UTP elicits a concentration-dependent $\mathrm{Ca}^{2+}$ response in BON cells in the range of $1 \mathrm{nM}-5 \mathrm{mM}$ (Figures $4 \mathrm{~A}-\mathrm{D}$ ). In this concentration range, a biphasic effect occurs with apparent $\mathrm{EC}_{50}$ values of 11.4 and $410 \mu \mathrm{M}$ UTP (Figure 4C). The best-fit curve for the first phase of the response is plotted with a logistic equation in Figure 4D. 

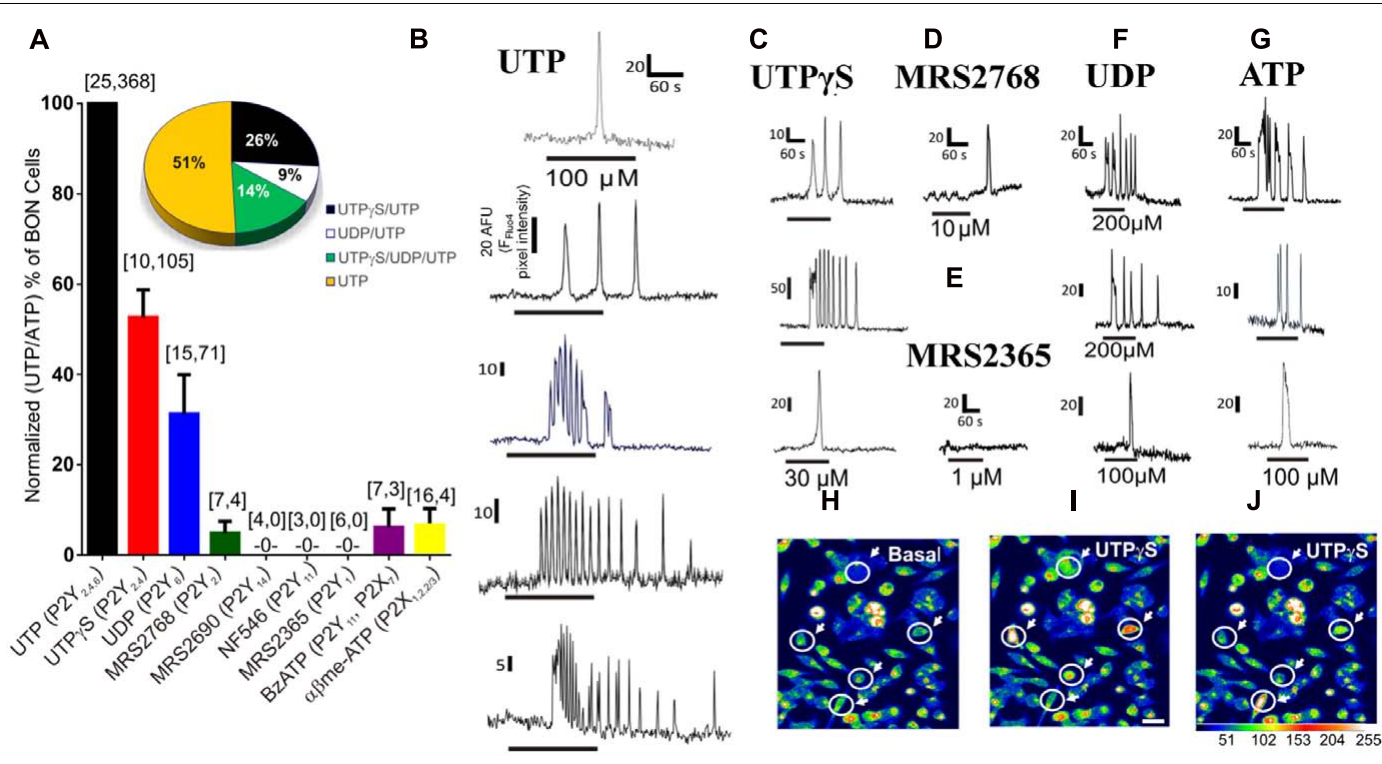

FIGURE 1 | Pharmacology of purinergic receptors linked to $\mathrm{Ca}^{2+}$ responses in BON cells. (A) Percentage of UTP (or ATP) responsive cells displaying Ca ${ }^{2+}$ responses to selective purinergic agonists. $\mathrm{Ca}^{2+}$ responses were normalized to \% of UTP or ATP responsive cells, since same subset of cells were always responsive to both agonists; the first number inside the brackets represents the number of cultures and the second is the number of responsive cells. The Ca ${ }^{2+}$ response to agonists follows the order of UTP/ATP $>$ UTP $\gamma S>$ UDP $>>$ MRS2768 $=$ BzATP $=\alpha, \beta-$ MeATP $>$ MRS2365, MRS2690, NF546. Pie graph inset shows the response patterns to agonists obtained from consecutive applications of UTP $\gamma \mathrm{S}$, UDP and UTP in the same cells of a single experiment, $n=69$ cells; repeated in $N=5$ cultures. Representative $\mathrm{Ca}^{2+}$ transients are shown for (B) UTP, (C) UTP $\gamma \mathrm{S}$, (D) MRS2768, (E) MRS2365, (F) UDP and (G) ATP. Line below the transient indicates duration of drug application. Each of the drugs was perfused at the concentrations indicated in Supplementary Table 1 for 1 min followed by ATP (or UTP) for UTP $\gamma$ S, UDP and MRS2768 or MRS2365) perfusion with a 10-15 min washout between each drug application. (H-J) Representative pseudocolor images of $\mathrm{Ca}^{2+}$ responses to $30 \mu \mathrm{M} \cup T P \gamma \mathrm{S}$, plotted on a pixel intensity scale from 0 to 255 . Responsive cells are circled with an arrow. Scale bar $=30 \mu \mathrm{m}$.

In summary, UTP activates multiple receptors in $\mathrm{BON}$ to evoke a $\mathrm{Ca}^{2+}$ response, but the predominant uridine nucleotide receptor operating in $\mathrm{BON}$ is the $\mathrm{P}_{2} \mathrm{Y}_{4}$ receptor. Subpopulations of responses to different agonists suggest that UTP, ATP and UDP can activate different combinations of purinergic receptors in different cells, and therefore, subtypes of EC cells can be distinguished by their functional expression of purinergic receptors.

\section{Expression of P2Y Receptors}

Western blot analysis for $\mathrm{P}_{2} \mathrm{Y}_{4}$ receptors identified a protein with a molecular weight of $\sim 50 \mathrm{kDa}$ in BON cells, EC cells, human mucosa, as well as human adenocarcinoid HT-29 epithelial cells, whereas immunogenic bands for $\mathrm{P}_{2} \mathrm{Y}_{2}$ were identified only in mucosa, and were absent from BON cells (Figures $4 \mathrm{E}, \mathbf{G}$ ). P2 $\mathrm{Y}_{6}$ immunogenic bands were identified in BON cells, mucosa, HT-29 and human enterochromaffin cells (hEC) isolated from surgical specimens (Figure 4F). Immunogenic bands were eliminated by pre-absorption of antisera with CP (Figures 4F,G).

TaqMan PCR analysis for $\mathrm{P}_{2} \mathrm{Y}_{4}$ and $\mathrm{P}_{2} \mathrm{Y}_{6}$ (the two main $\mathrm{P} 2 \mathrm{Y}$ receptors identified in pharmacological studies) indicated that mRNA expression for $\mathrm{P}_{2} \mathrm{Y}_{4}$ was much higher than $\mathrm{P}_{2} \mathrm{Y}_{6}$ in BON cells (Figure $\mathbf{4 H}$ ). As shown in Supplementary Figure 2, mRNA expression level of $\mathrm{P}_{2} \mathrm{Y}_{6}$ is passage dependent in $\mathrm{BON}$ cells. Therefore, in passages $<36,64 \%$ of UTP responsive cells respond to UDP $\left(\mathrm{P}_{2} \mathrm{Y}_{6}\right)$ whereas in passages $>43$ only $9 \%$ of UTP responsive cells, respond to UDP. Regardless of passage, $\sim 50 \%$ of
$\mathrm{UTP}$ responsive cells respond to $\mathrm{UTP} \gamma \mathrm{S}\left(\mathrm{P}_{2} \mathrm{Y}_{4}\right)$. Our studies were conducted in cells with both functional receptors present.

The western blot expression of the $\mathrm{P}_{2} \mathrm{Y}_{4}$ receptor was confirmed by immunofluorescent labeling to show expression of $\mathrm{P}_{2} \mathrm{Y}_{4}$ immunoreactivity in BON cells co-expressing 5-HT immunoreactivity (Figure 5) and EC cells (Figure 6). Abundant $\mathrm{P}_{2} \mathrm{Y}_{4}$ immunoreactivity is expressed in the cells. Our study was not designed to detect whether the $\mathrm{P}_{2} \mathrm{Y}_{4}$ receptors were localized to the surface of the cells. This could be done by radioimmunoassay (Brinson and Harden, 2001) and confirmed by detailed $\mathrm{z}$-stack confocal imaging experiments to determine whether $\mathrm{P}_{2} \mathrm{Y}_{4}$ is localized in the membrane or is also in the cytosol. $\mathrm{P}_{2} \mathrm{Y}_{4}$ receptors can undergo internalization upon activation, and receptors are expected to distribute in both membranes and inside the cell. Our pharmacological data support a functional role for the $\mathrm{P}_{2} \mathrm{Y}_{4}$ receptor.

\section{UTP Modulation of 5-HT Release}

It is well known that EC cells are the main source of 5-HT of the entire body and as anticipated, UTP and ATP stimulated 5-HT release from BON cells (Figure 6A) or hEC (Figure 6B) isolated from surgical specimens (Figures 6A,B). However, UTP was more effective in stimulating 5-HT release than ATP at equimolar concentrations (100 $\mu \mathrm{M}$ each). Furthermore, immunoreactivity for $\mathrm{P}_{2} \mathrm{Y}_{4}$ receptors was also confirmed in hEC cells (Figure 6D) as shown to occur in BON cells (Figure 5). Western blot analysis 


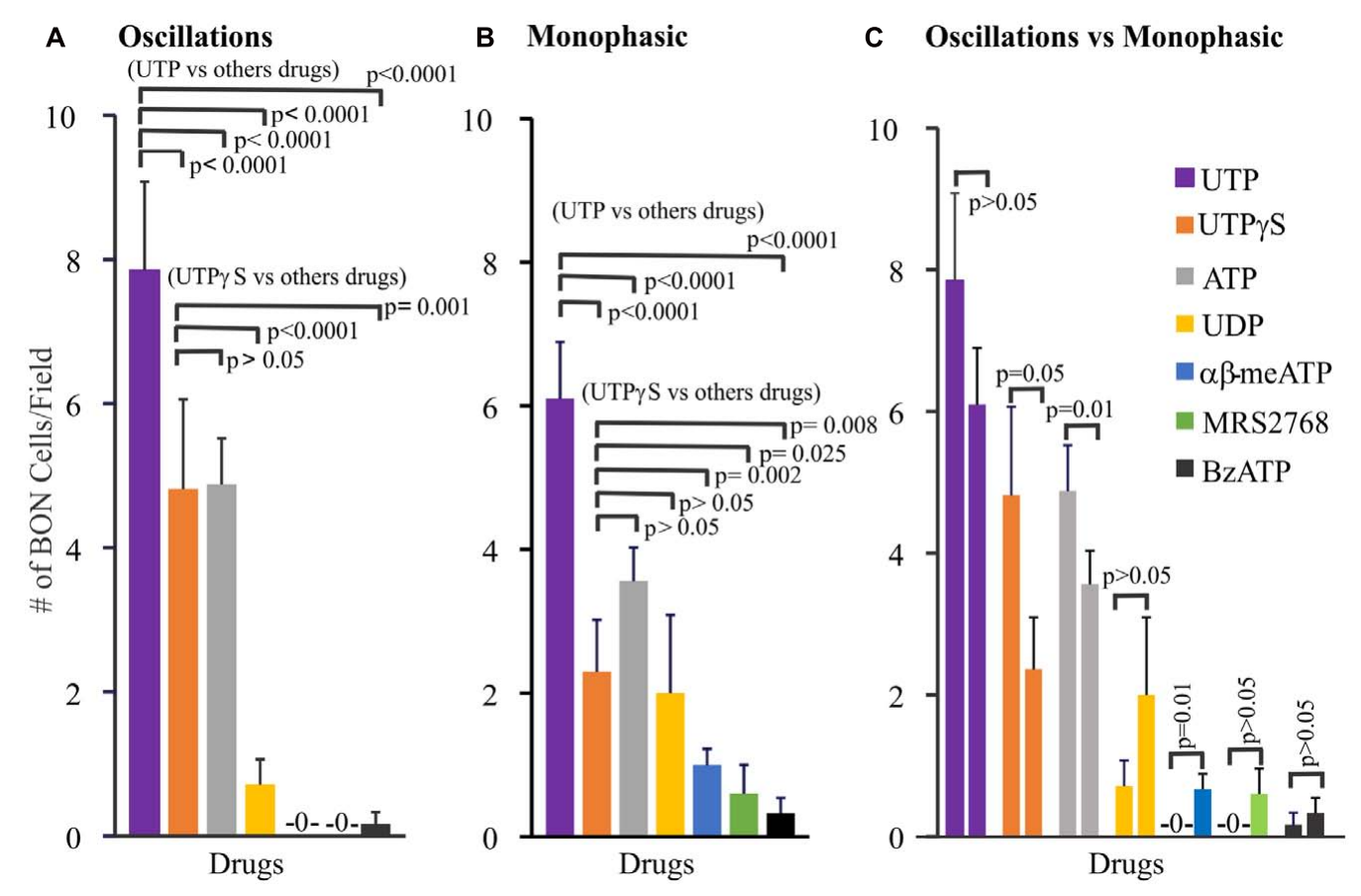

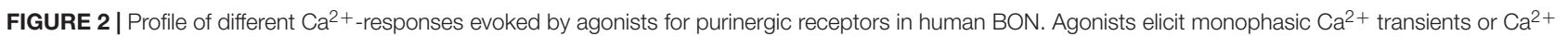
oscillations. (A) Profile of agonist responses for $\mathrm{Ca}^{2+}$ oscillations. (B) Profile of agonist responses for monophasic $\mathrm{Ca}^{2+}$ transients. (C) Comparison of the number of cells displaying oscillations (first column) versus monophasic (second column) $\mathrm{Ca}^{2+}$ transients in response to each purinergic agonist. Poisson regression was used for statistical comparisons in $(\mathbf{A}, \mathbf{B})$, and $t$-test in $\mathbf{( C )}$. For this analysis only one drug at a time was tested in each cell culture. Concentrations of each drug are listed in Supplementary Table 1 (see results for more details). The average number of cells/field was $46 \pm 8$. The proportion of cells responding to UTP is $\sim 20 \%$; for UTP $\gamma$ S, it was $11 \%$.

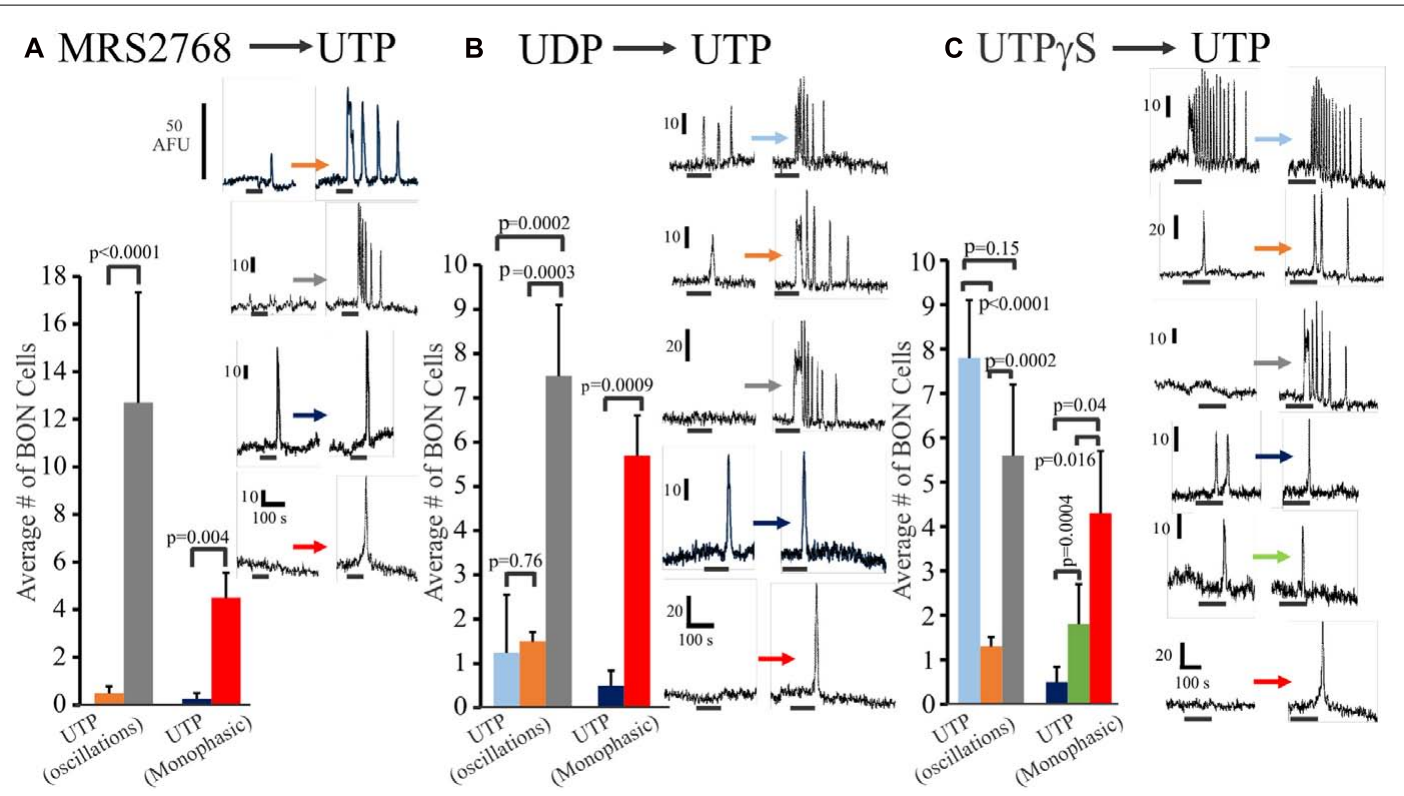

FIGURE 3 | Oscillations or monophasic $\mathrm{Ca}^{2+}$ transients involve $\mathrm{P}_{2} \mathrm{Y}_{4}$ and $\mathrm{P} 2 \mathrm{Y}_{6}$ receptors in human $\mathrm{BON}$. Ca ${ }^{2+}$ responses to consecutive applications of (A) a P2Y 2 agonist MRS2768, (B) a P2Y 6 agonist UDP or (C) a P2Y 2,4 agonist UTP $\gamma$ S followed by UTP (washout of 10 min, drugs tested in 4-5 separate cultures). The color of each column represents a particular type of response that is illustrated in representative $\mathrm{Ca}^{2+}$ transients at the right of each histogram. For example, in (A), the gray bar represents cells with no response to MRS2768 and $\mathrm{Ca}^{2+}$ oscillations to UTP. The red bar represents cells with no response to MRS2768 and a monophasic $\mathrm{Ca}^{2+}$ transient to UTP. UTP $\gamma \mathrm{S}$ in contrast to UDP more closely mimics responses to UTP in a significant proportion of cells. 

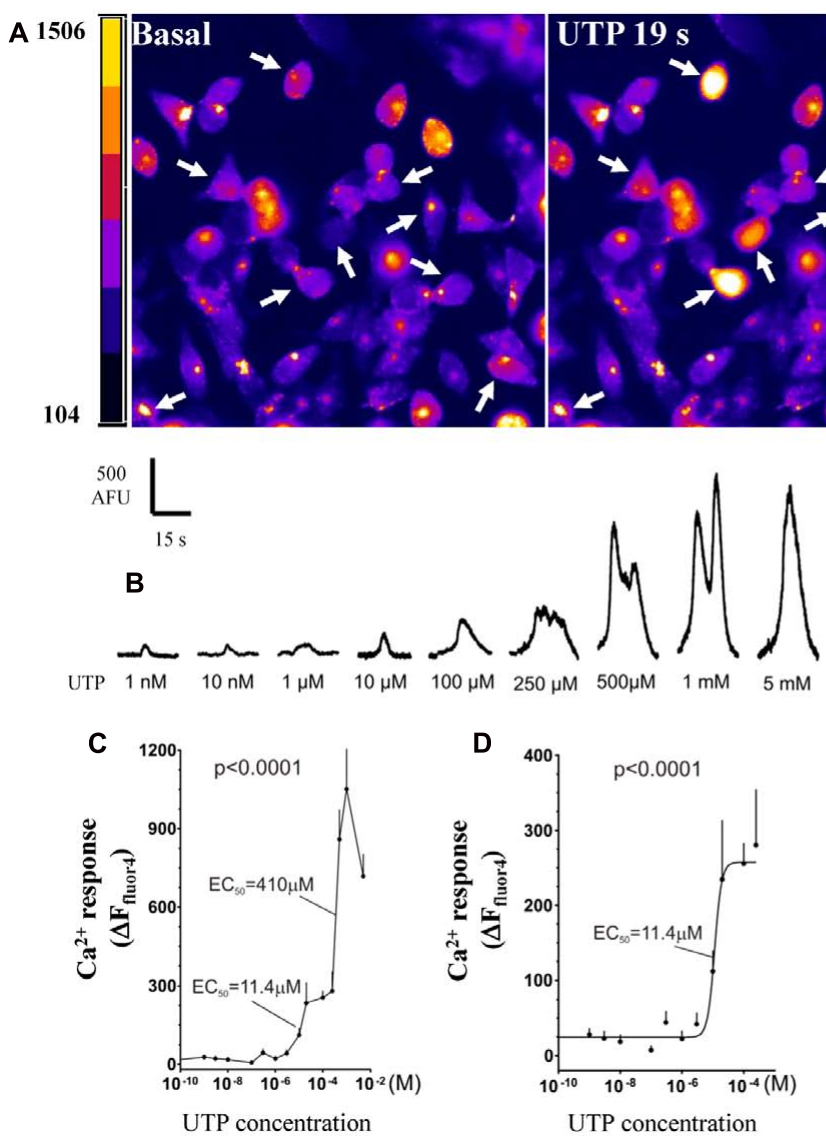

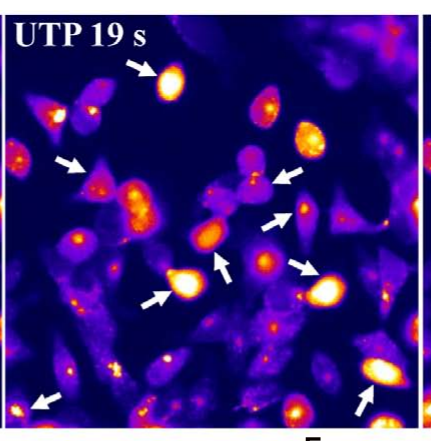

E
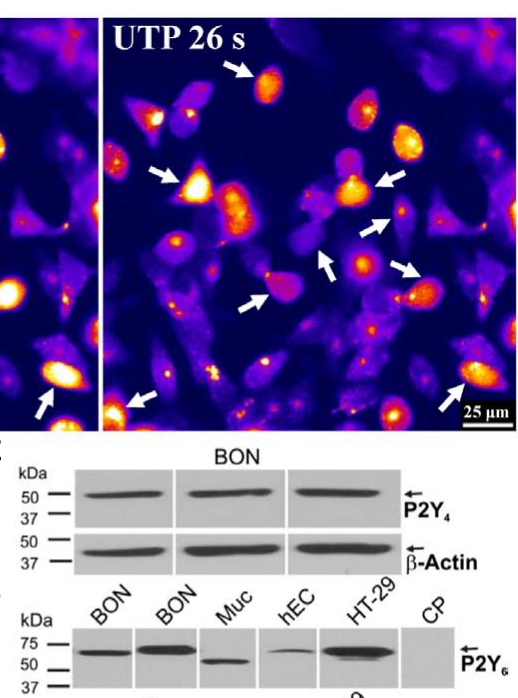

BON

G
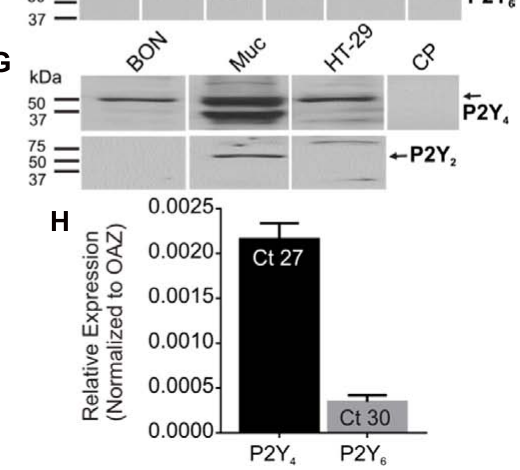

FIGURE 4 | Function and molecular characteristics of uridine nucleotide receptors activated by UTP. (A,B) UTP elicits a concentration dependent Ca ${ }^{2+}$ response in BON. (A) Representative images of BON cells in response to $100 \mu \mathrm{M}$ UTP perfusion. Cells responding to UTP with a Ca ${ }^{2+}$ response are marked with an arrow; pseudocolor images based on pixel intensity (0-1500 arbitrary units). (B) Representative $\mathrm{Ca}^{2+}$ transients to separate applications of UTP in the concentration range of $1 \mathrm{nM}$ to $5 \mathrm{mM}$. (C) Biphasic concentration-response curve to UTP for peak $\mathrm{Ca}^{2+}$ responses. ANOVA, $p<0.0001$ (310 cells were analyzed). The apparent EC 50 of the first phase of the response is $11.4 \mu \mathrm{M}$; the $\mathrm{EC}_{50}$ of the second phase is $410 \mu \mathrm{M}$. (D) The first phase of the UTP concentration - response curve $(0.1 \mathrm{nM}-0.2 \mathrm{mM})$ is fitted with a logistic equation; symbols represent the net increase in $\mathrm{Ca}^{2+}$ response at each time point and the error bars are SEM $(n=15$ or more cells at each concentration). (E) Representative western blots (WB) showing immunogenic bands for P2Y $\mathrm{R}$ in BON cells. (F) Representative immunogenic bands for $\mathrm{P}_{2} \mathrm{Y}_{6} \mathrm{R}$ in BON, human mucosa (Muc) and isolated human EC cells from surgical specimens (hEC), and human HT-29 cells. Pre-absorption of the anti-P2Y ${ }_{6} R$ antibody with its immunogenic peptide (CP) blocked the immunogenic bands. (G) P2Y is detected in BON, Muc and HT-29 cells. P2Y ${ }_{2} R$ is only detected in the human mucosa and not BON or HT-29. (H) TaqMan PCR analysis showing the relative expression of P2Y $\mathrm{R}_{4}$ and $\mathrm{P} 2 \mathrm{Y}_{6} \mathrm{R}$ normalized to $\mathrm{OAZ}_{\mathrm{Z}}$ as $2^{\wedge}(-\Delta \mathrm{Ct})$. The $C_{t}$ values are indicated inside each column, $N=6$ cultures. BON cells for qPCR were tested at passage 44 , and $\mathrm{P} 2 \mathrm{Y}_{4}$ expression was $>\mathrm{P}_{2} \mathrm{Y}_{6}$ expression (see Results and Supplementary Figure 2).

identified the 5-HT synthesizing enzyme (TPH1) in both hEC and BON cells (Figure 6C).

In hEC cells identified by their 5-HT immunoreactivity and DAPI counter stain, $28.82 \pm 12.43 \%$ of 694 cells express $\mathrm{P}_{2} \mathrm{Y}_{4}$ receptor immunoreactivity. Cells were counted in 20 random fields from cells isolated from jejunum surgical specimens in two patients. A caveat here is that this is a pilot analysis, and it may not represent the population response in human jejunum EC cells. It is important to point out that that $\mathrm{P}_{2} \mathrm{Y}_{4}$ receptors can undergo internalization after activation by a high enough concentration of UTP (Brinson and Harden, 2001), and the EC cell isolation procedure used is sufficient to mechanically activate the cells to release UTP (or other purines) and cause receptor internalization to varying degrees in the cells. Cells can take many hours to recover (i.e., up to $12 \mathrm{~h}$ ). Apparently, there are both punctate and other staining distributions in different EC cells (probably representing localization at both cell surface and inside the cells). EC cells are sensitive to mechanical stimulation, and even changing the medium on the cells after plating can cause release of UTP (Lazarowski et al., 1997; Lazarowski and Harden, 1999) that can activate receptors.

\section{$\mathrm{Ca}^{2+}$ Signaling Pathways Activated by UTP}

5-HT release is a $\mathrm{Ca}^{2+}$ dependent mechanism, and therefore, we sought to determine the post-receptor signaling pathways linked to UTP $-\mathrm{Ca}^{2+}$ responses. Comprehensive analysis was done with pharmacological inhibitors, receptor or channel blockers, and data is summarized in Tables 2, 3. As well, given the complexity of 


\section{A}

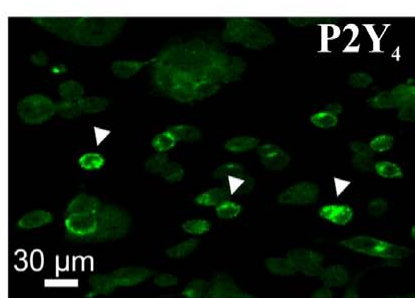

B

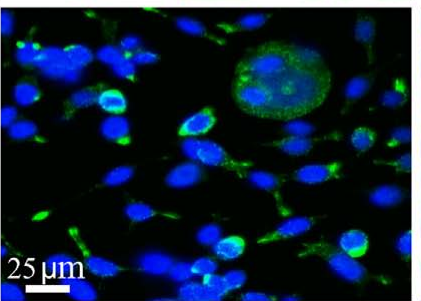

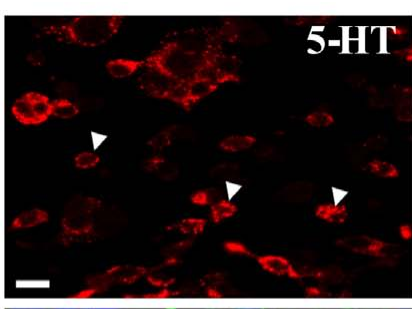


FIGURE 5 | P2Y ${ }_{4}$ R immunoreactivity in BON cells. (A) Co-labeling of $\mathrm{P}_{2} \mathrm{Y}_{4}$ receptors (green) with 5-HT (red) in BON cells. P2Y is co-localized in a subset of BON cells expressing 5-HT immunoreactivity; arrowheads, co-localization of $\mathrm{P}_{2} \mathrm{Y}_{4}$ and $5 \mathrm{HT}$ immunoreactivities. (B) BON cells labeled for $\mathrm{P} 2 \mathrm{Y}_{4}$ immunoreactivity (green)

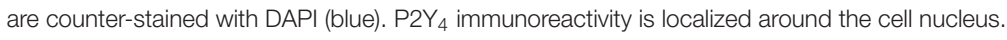
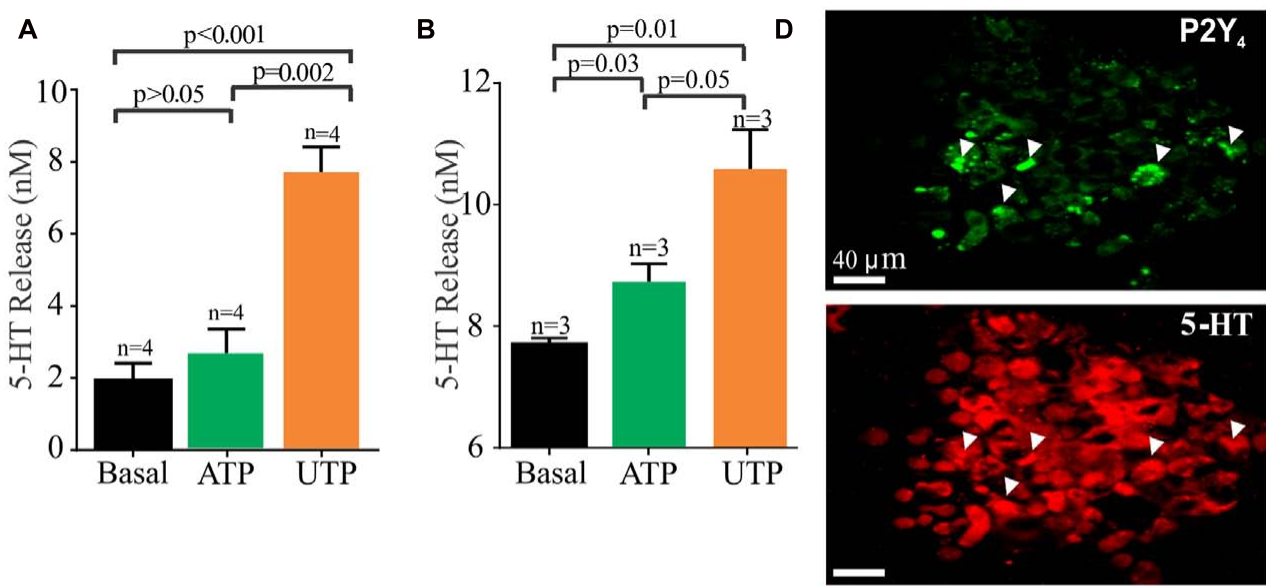

C
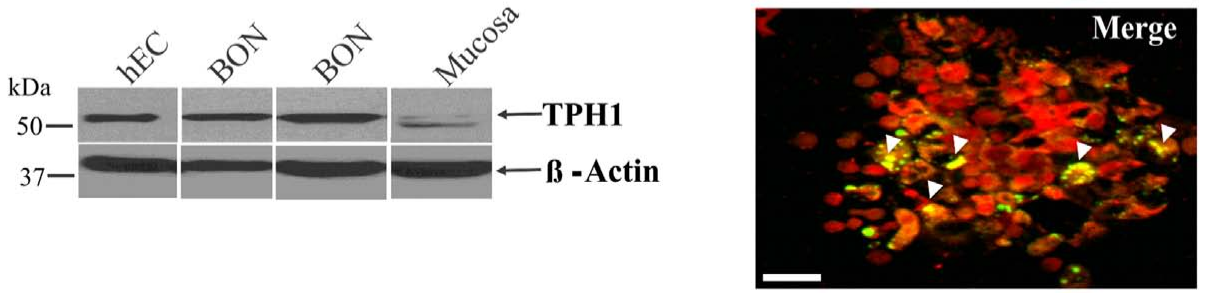

FIGURE 6 | UTP stimulates 5-HT release in BON cells and human EC cells isolated from surgical specimens. (A) UTP stimulates 5-HT release in BON. (B) UTP stimulates 5-HT release in human EC cells; UTP and ATP are applied at $100 \mu \mathrm{M}$ each. (C) Western blot showing TPH1 expression in human EC cells, BON cells and human mucosa; $\beta$-actin is used as a housekeeping gene. Samples were run in the same gel. (D) Co-labeling for P2Y ${ }_{4}$ and 5 -HT immunoreactivity in human EC cells isolated from human surgical specimens.

the pathway, we decided to present the results for $\mathrm{Ca}^{2+}$ imaging and patch-clamp separately.

As a GPCR, P2Y 4 may couple to the $\mathrm{G}_{\mathrm{q}}$ protein. The PLC inhibitor U73122 prevented the UTP $-\mathrm{Ca}^{2+}$ response in $69 \%$ of the cells and reduced the response in the remainder (Figure 7). Both types of responses, oscillations and monophasic $\mathrm{Ca}^{2+}$ transients to UTP were blocked by U73122 (Figures 7A,B).
However, in a subset of cells, $\mathrm{Ca}^{2+}$ oscillations were only partially blocked by U73122 (Figure 7C). The effect of U73122 was selective for PLC since the inactive analog U73343 could not block UTP $\mathrm{Ca}^{2+}$ responses (Figures 7D-F).

To evaluate the role of external calcium on the rise of intracellular calcium, we tested the $\mathrm{Ca}^{2+}$ channel blocker lanthanum $\left(\mathrm{La}^{3+}\right)$, which could abolish UTP $-\mathrm{Ca}^{2+}$ transients 
TABLE 2 | Post-receptor signaling pathways linked to UTP-Ca ${ }^{2+}$ responses.

\begin{tabular}{|c|c|c|c|c|c|}
\hline Drug (+UTP) & {$[\mu \mathrm{M}]$} & $\begin{array}{l}\text { Effect on UTP } \mathrm{Ca}^{2+} \\
\text { oscillations }\end{array}$ & Mechanism & $n$ & $p$-value \\
\hline $0 \mathrm{Ca}^{2+}$ EGTA & 500 & $\begin{array}{l}\text { Augmented the average } \\
\text { response }\end{array}$ & $\mathrm{Ca}^{2}+$ chelator & 45 & $0.038^{b}$ \\
\hline BAPTA-AM & 50 & Blocked in $100 \%$ of the cells & $\mathrm{Ca}^{2+}$ chelator & 23 & $<0.001^{\mathrm{a}}$ \\
\hline U73122 vs. U743343 & 10 & $\begin{array}{l}\text { Blocked in } 69 \% \text { of the cells } \\
\text { Average inhibition of } 73 \%\end{array}$ & PLC inhibitor & $\begin{array}{l}16 \\
23\end{array}$ & $\begin{array}{l}0.001^{a} \\
0.0001^{a}\end{array}$ \\
\hline $\mathrm{La}^{3+}$ & 100 & Blocked in $100 \%$ of the cells & $\mathrm{Ca}^{2+}$ channel blocker & 57 & $<0.0001^{\mathrm{a}}$ \\
\hline 2APB & 100 & Blocked in $100 \%$ of the cells & IP3r antagonist, inhibits SOC release & 27 & $<0.0001^{\mathrm{a}}$ \\
\hline Thapsigargin & 1 & Blocked in $100 \%$ of the cells & $\mathrm{Ca}^{2+}$ pump SERCA inhibitor & 16 & $0.001^{\mathrm{a}}$ \\
\hline RuRed & 10 & No effect & Ryanodine receptor blocker & 12 & $N S^{b}$ \\
\hline Ly29400 & 10 & No effect & PI3K inhibitor & 28 & $N S^{b}$ \\
\hline GF109203X & 1,3 & No effect & PKC inhibitor & 10,32 & $N S^{b}$ \\
\hline MRS1845 & 20 & No effect & Inhibits store-operated $\mathrm{Ca}^{2+}$ entry & 33 & $N S^{b}$ \\
\hline PP2 & 10 & No effect & SRC kinase blocker & 20 & $N S^{b}$ \\
\hline SKF96365 & 50 & No effect & $\begin{array}{l}\text { TRPC channel blocker; also inhibits store-operated } \mathrm{Ca}^{2+} \\
\text { entry, voltage-gated } \mathrm{Ca}^{2+} \text { channels and potassium } \\
\text { channels }\end{array}$ & 15 & $N S^{b}$ \\
\hline Nicardipine & 10 & No effect & L-type VOCC blocker & 18 & $N S^{b}$ \\
\hline
\end{tabular}

a Paired t-test, ${ }^{\mathrm{b}}$ unpaired t-test.

TABLE 3 | UTP modulates BON cells MP by fine tuning of a number of ionic conductances.

\begin{tabular}{|c|c|c|c|c|c|}
\hline Drug & Condition & Description & $p$-value & MP Depolarization (mV) & Increase in $\mathrm{I}_{\mathrm{Ca}}{ }^{2+}$ \\
\hline UTP & $100 \mu \mathrm{M}$ (3 min) & $\begin{array}{l}\mathrm{P}_{2} \mathrm{Y}_{2,4,6} \text { endogenous } \\
\text { agonist }\end{array}$ & $\mathrm{n} / \mathrm{a}$ & $5.94 \pm 0.88 n=17 / 34 ;(\uparrow R i)$ & $\begin{array}{c}p<0.0001 ; n=10\left(V_{m}-20 \text { to }\right. \\
40 \mathrm{mV})\end{array}$ \\
\hline UTP $\gamma \mathrm{S}$ & $30 \mu \mathrm{M}(3 \mathrm{~min})$ & $\mathrm{P} 2 \mathrm{Y}_{2,4}$ agonist & $\mathrm{n} / \mathrm{a}$ & $\mathrm{n} / \mathrm{a}$ & $\begin{array}{c}p<0.0001 ; n=6\left(V_{m}-30 \text { to }\right. \\
20 \mathrm{mV})\end{array}$ \\
\hline UDP & 100 нM (3 min) & $\mathrm{P} 2 \mathrm{Y}_{6}$ agonist & $P>0.05$ & $\mathrm{n} / \mathrm{a}$ & $\begin{array}{c}\mathrm{I}_{\mathrm{Ca}}, p=\mathrm{NS} ; n=8 \text { Voltage } \\
\text { dependence, } p=0.028 ; n=8 \\
\left(\mathrm{~V}_{50}-13.6 \text { to }-7.9\right)\end{array}$ \\
\hline $\begin{array}{l}\mathrm{Ca}^{2+} \text { free E.S. }+ \\
\text { EGTA }\end{array}$ & $\mathrm{n} / \mathrm{a}$ & $\begin{array}{l}\mathrm{VOCa}^{2+} \text { channels } \\
\text { inhibition }\end{array}$ & $P>0.05$ & $\begin{array}{c}4.66 \pm 1.38,3.70 \pm 0.47 \\
n=9-10\end{array}$ & $\mathrm{n} / \mathrm{a}$ \\
\hline Lanthanum ${ }^{3+}$ & $100 \mu(10 \mathrm{~min})$ & $\begin{array}{l}\text { VOCa }{ }^{2+} \text { channels } \\
\text { blocker }\end{array}$ & $P>0.05$ & $\begin{array}{c}6.90 \pm 1.05,4.93 \pm 1.07 \\
n=8-11\end{array}$ & $\mathrm{n} / \mathrm{a}$ \\
\hline Thapsigargin & $1 \mu \mathrm{M}$ (10 min) & SERCA inhibitor & $P>0.05$ & $\begin{array}{c}4.90 \pm 1.14,6.18 \pm 1.29 \\
n=11\end{array}$ & $\mathrm{n} / \mathrm{a}$ \\
\hline $\begin{array}{l}\text { U73122 vs. } \\
\text { U73343 }\end{array}$ & $2.5 \mu \mathrm{M}(5 \mathrm{~min})$ & PLC antagonist & $P<0.05, x^{2}$ & \# cells: $0 / 8,5 / 12$ & $\mathrm{n} / \mathrm{a}$ \\
\hline GF109203X & $0.5 \mu \mathrm{M}(10 \mathrm{~min})$ & $\begin{array}{l}\text { PKC } \alpha, \beta I, \beta \|, \delta \text { and } \varepsilon \\
\text { inhibitor }\end{array}$ & $P>0.05$ & $6.00 \pm 1.00,7.66 \pm 1.45 n=3$ & $\mathrm{n} / \mathrm{a}$ \\
\hline UTP vs. UTP $\gamma \mathrm{S}$ & $30 \mu \mathrm{M}(3 \mathrm{~min})$ & $\mathrm{P} 2 \mathrm{Y}_{2,4}$ agonist & $P>0.05$ & $\begin{array}{c}7.16 \pm 1.74,6.83 \pm 2.08 \\
n=6 ;(\uparrow R i)\end{array}$ & $\mathrm{n} / \mathrm{a}$ \\
\hline UTP $\gamma \mathrm{S},+$ UTP & $30 \mu \mathrm{M}(3 \mathrm{~min})$ & $\mathrm{P}_{2} \mathrm{Y}_{2,4}$ agonist & $P<0.05$ & $8.30 \pm 2.08,0.40 \pm 0.24 n=5$ & $\mathrm{n} / \mathrm{a}$ \\
\hline UTP vs. XE-991 & $10 \mu \mathrm{M}(10 \mathrm{~min})$ & $\begin{array}{l}\mathrm{Kv} 7.1,7.2 \text { and } 7.3 \\
(\mathrm{KCNQ}) \text { blocker }\end{array}$ & $P>0.05$ & $\begin{array}{c}5.13 \pm 0.64,6.08 \pm 0.82 \\
n=8-12 ;(\uparrow R i)\end{array}$ & $\mathrm{n} / \mathrm{a}$ \\
\hline UTP, +XE-991 & $10 \mu \mathrm{M}(10 \mathrm{~min})$ & $\begin{array}{l}\text { Kv7.1,7.2 and } 7.3 \\
\text { (KCNQ) blocker }\end{array}$ & $P<0.05, \chi^{2}$ & \# cells: 8/15, 2/17 & $\mathrm{n} / \mathrm{a}$ \\
\hline
\end{tabular}

in $100 \%$ of cells in a partially reversible manner (Figures $\mathbf{8 A , G}$ ). Next, to assess the role of intracellular calcium stores, we treated the cells with the IP3R antagonist $2 \mathrm{APB}$, which could also abolish the UTP-Ca ${ }^{2+}$ transients, and the effect was partially reversible with washout of the drug (Figures $\mathbf{8 B}, \mathbf{H}$ ). In a similar way, the sarco/endoplasmic reticulum (SERCA) $\mathrm{Ca}^{2+}$ ATPase inhibitor thapsigargin, abolished all UTP-responses in an irreversible manner (Figures 8C,I).
To further dissect the signaling pathway, we used different treatments targeting several possibilities based on our previous results; however, they were without effect on UTP-Ca ${ }^{2+}$ responses (Table 2). These included treatment with a ryanodine receptor blocker (RuRed, Figures 8D,J), a selective inhibitor of store-operated $\mathrm{Ca}^{2+}$ entry (SOC channels, MRS1845; Figures 8E,K), a PI3K blocker (Ly294002, Supplementary Figure 3A), a PKC antagonist (GF109203X, Supplementary 


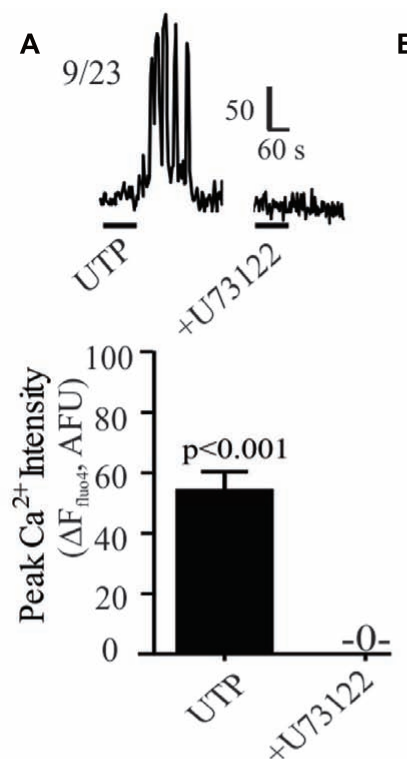

D



B
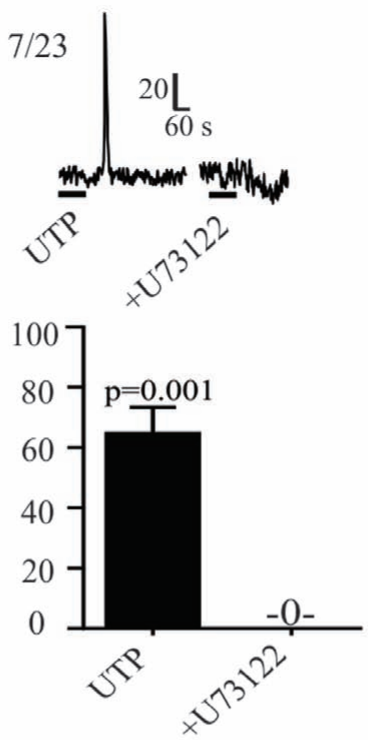

E

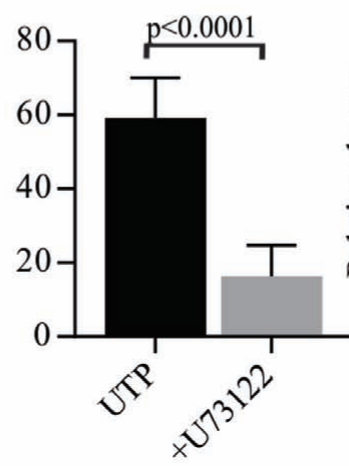

C
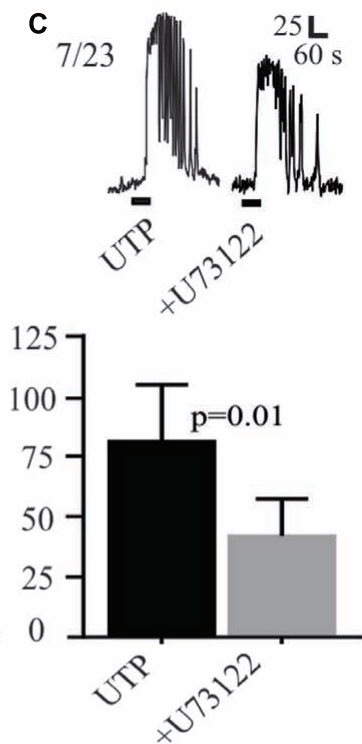

$\mathbf{F}$

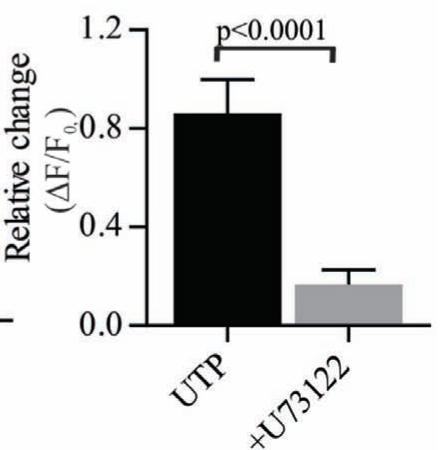

FIGURE 7 | UTP-Ca ${ }^{2+}$ responses depend on the phospholipase C (PLC) signaling pathway in human BON. The PLC inhibitor U73122 (10 $\mu$ M) abolished the Ca ${ }^{2+}$ responses induced by UTP (A) in cells with $\mathrm{Ca}^{2+}$ oscillations or (B) monophasic $\mathrm{Ca}^{2+}$ transients, (C) and reduced $\mathrm{Ca}^{2+}$ responses in other cells. Representative $\mathrm{Ca}^{2+}$ responses are shown in (A-C) and histograms associated with each type of response represent pooled data showing that U73122 can abolish or reduce $\mathrm{Ca}^{2+}$ responses. (D-F) Average population response showing that U73122 but not its inactive analog U73343, can block UTP-Ca ${ }^{2+}$ responses in BON (EC) cells. Cells were pre-incubated with U73122 or U73343 for $10 \mathrm{~min}$.

Figure 3B), and a SRC kinase antagonist (PP2, Supplementary Figure $3 \mathrm{C}$ ), which did not affect the UTP $-\mathrm{Ca}^{2+}$ response. To further clarify the effect of $\mathrm{La}^{3+}$ on UTP-evoked oscillations, we tested inhibitors of other mechanisms that could potentially be involved in external calcium conductance. Therefore, the SOCE/TRPC channel blocker (SKF96365, Supplementary Figure 3D) and a blocker of the L-type voltage dependent $\mathrm{Ca}^{2+}$ channel, previously linked to 5-HT release (nicardipine, see Figures 8F,L) had no effect on UTP $\mathrm{Ca}^{2+}$ responses. Taken together, the data suggest that UTP $\mathrm{Ca}^{2+}$ responses are linked to a $\mathrm{P}_{2} \mathrm{Y}_{4} / \mathrm{Gq} / \mathrm{PLC} / \mathrm{IP} 3 / \mathrm{IP} 3 \mathrm{R} / \mathrm{SERCA}-\mathrm{Ca}^{2+}$ pump - $\mathrm{Ca}^{2+}$ signaling pathway.

We further evaluated the effect of depleting intracellular or extracellular $\mathrm{Ca}^{2+}$ levels. We found that that these manipulations had opposite effects on UTP-evoked $\mathrm{Ca}^{2+}$ responses (Figure 9). On the one hand, the intracellular free $\mathrm{Ca}^{2+}$ chelator BAPTA-AM could abolish the UTP $\mathrm{Ca}^{2+}$ response in BON cells (Figures 9A,B). On the other hand, bathing the cells in Krebs buffer with $0.0 \mathrm{Ca}^{2+}+$ EGTA enhanced rather than suppressed UTP-evoked $\mathrm{Ca}^{2+}$ responses (Figures 9C-E) without affecting its duration (not shown). Finally, we evaluated whether or not this augmented intracellular calcium response may alter the magnitude of 5-HT release evoked by UTP and we found that, in BON cells, $0.0 \mathrm{Ca}^{2+}+$ EGTA in the extracellular bathing medium could enhance the UTP-evoked 5-HT release (Figure 9F).

\section{Molecular Signaling Pathways Linked to UTP-Induced MP Depolarization}

UTP was shown to cause a prominent increase in intracellular free $\mathrm{Ca}^{2+}$ levels, and therefore we sought to determine whether or not this increase in $\mathrm{Ca}^{2+}$ via $\mathrm{P} 2 \mathrm{Y}$ receptor activation modulates the membrane potential of BON cells. To do so, we used perforated patch clamp to access and record membrane 

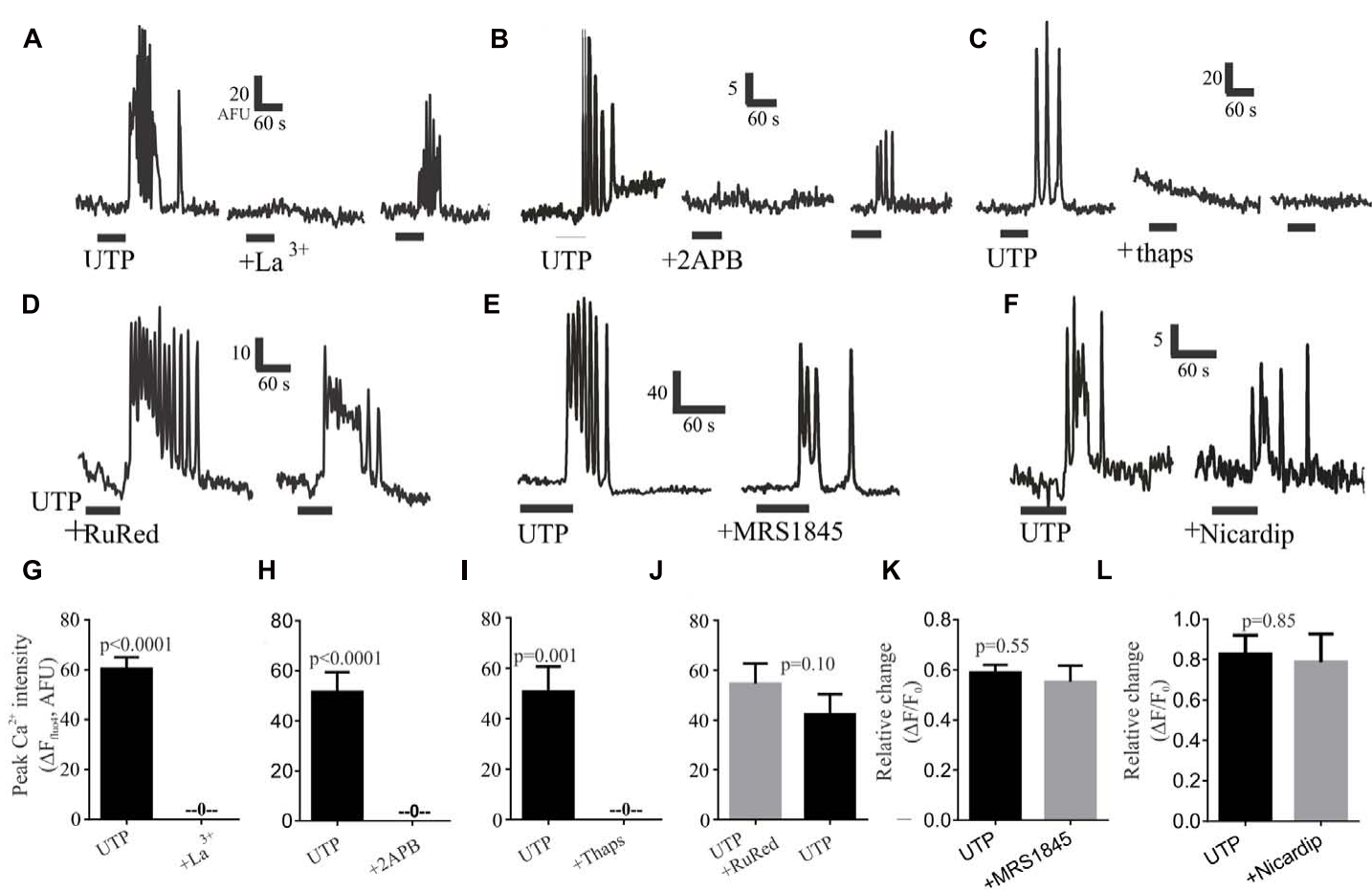

FIGURE 8 | Post-receptor signaling pathways linked to UTP-Ca ${ }^{2+}$ responses in BON cells. Representative $\mathrm{Ca}^{2+}$ responses showing that (A) $100 \mu \mathrm{M} \mathrm{La}^{3+}$, (B) $10 \mu \mathrm{M} 2 \mathrm{APB}$ or (C) $1 \mu \mathrm{M}$ thapsigargin (thaps) can block UTP-induced Ca ${ }^{2+}$ transients. In Contrast, (D) RuRed, (E) $20 \mu \mathrm{M}$ MRS1845 or (F) $10 \mu \mathrm{M}$ nicardipine are not effective in blocking UTP-induced $\mathrm{Ca}^{2+}$ transients. After washing-out the drug (15 min) a partial recovery of the UTP-response was seen for La ${ }^{3+}$ and $2 \mathrm{APB}$ but not for thapsigargin (thaps). (G-L) Pooled data for effects of each of the treatments illustrated in (A-F) indicating that $\mathrm{La}^{3+}, 2 \mathrm{APB}$ or thaps can abolish $\mathrm{Ca}^{2+}$ transients $\left(p<0.001\right.$ for each) whereas RuRed, MRS1845 or Nicardipine did not significantly reduce UTP-induced Ca ${ }^{2+}$ transients $(p>0.05)$. Table 2 provides detailed description of the inhibitors. The test group involved UTP application followed by UTP + inhibitor in the same cells (with a 10 min recovery time allowed between each drug application. A control group involved two consecutive applications of UTP ( $p>0.05$ between peaks in two consecutive applications, not shown).

potential $\left(\mathrm{V}_{\mathrm{m}}\right)$ at rest and during drug stimulation. As expected, UTP induced a slow developing $\mathrm{V}_{\mathrm{m}}$ depolarization in $50 \%$ of cells (17 of $34 \mathrm{BON}$ cells). This effect peaked at $\sim 60 \mathrm{~s}$ of application and lasted several min after UTP washout (Figures 10A,C $5.94 \pm 0.88 \mathrm{mV}$ depolarization; $n=17$ ). Surprisingly, UTP-evoked $\mathrm{V}_{\mathrm{m}}$ depolarization was associated with a significant increase in $\mathrm{R}_{\mathrm{i}}$ (Figure 10D, $1.11 \pm 0.12 \mathrm{G} \Omega$ for control versus $1.46 \pm 0.16 \mathrm{G} \Omega$ for UTP; $p=0.01$, $n=7)$.

As our previous results demonstrated $\mathrm{P}_{2} \mathrm{Y}_{4}$ plays a major role in UTP responses in these cells, we tested UTP $\gamma \mathrm{S}$ to determine the association of this receptor with the UTP-evoked $\mathrm{V}_{\mathrm{m}}$ depolarization. In a similar manner, the $\mathrm{P}_{2} \mathrm{Y}_{4}$ agonist UTP $\gamma \mathrm{S}$ caused a slow membrane depolarization equivalent to that of UTP (Figure 10F), associated with an increase in $\mathrm{R}_{\mathrm{i}}$ (Figure 10D, $1.17 \pm 0.10 \mathrm{G} \Omega$ for control versus $1.38 \pm 0.15 \mathrm{G} \Omega$ for UTP $\gamma S$; $p=0.038, n=6$ ); maximal depolarization was also reached at $\sim 60 \mathrm{~s}$ and lasted for several min after washing out UTP $\gamma$ S. Furthermore, activation of $\mathrm{P}_{2} \mathrm{Y}_{4}$ receptors by previous application of UTP $\gamma \mathrm{S}$ prevented the UTP-evoked $\mathrm{V}_{\mathrm{m}}$ depolarization (Figures 10B,E: $8.30 \pm 2.08 \mathrm{mV}$ for UTP $\gamma \mathrm{S}$ and $0.40 \pm 0.24 \mathrm{mV}$ for UTP in the continued presence of UTP $\gamma ; p=0.0165, n=5$ ). ATP caused a similar $\mathrm{V}_{\mathrm{m}}$ depolarization to UTP, and prior application of ATP to depolarize the cell prevented any further response of UTP (Supplementary Figure 4). Therefore, activation of a $\mathrm{P}_{2} \mathrm{Y}_{4}$ receptor also causes $\mathrm{V}_{\mathrm{m}}$ depolarization of BON cells.

To further dissect the intracellular pathway activated by UTP to cause $\mathrm{V}_{\mathrm{m}}$ depolarization and in parallel with $\mathrm{Ca}^{2+}$ imaging studies, pharmacological studies with inhibitors were done. Data is summarized in Table 3.

First of all, we sought to determine whether or not activation of P2Y was associated with PLC. The UTP induced $V_{m}$ depolarization was completely abolished in the presence of the PLC inhibitor U73122 (Figures 11A,E), but not with the inactive compound U73343 (Figures 11B,E, 0 out 8 cells and 5 out of 12 cells, respectively, responded to UTP, $p=0.035$ ). This may suggest a reduction in $\mathrm{K}^{+}$conductance, an $\mathrm{I}_{\mathrm{K}}$ current.

Since UTP-induced $\mathrm{V}_{\mathrm{m}}$ depolarization was associated with an increase in $R_{i}$ and previous studies reported $U T P / P 2 Y_{4}$ can regulate potassium conductance via $G_{q} / P L C$ (type $M$ currents) (Falkenburger et al., 2010), we wanted to assess if the effect of UTP in BON cells was associated with the modulation of the same conductance. Therefore, we tested XE-991, a selective Kv7.1/7.2/7.3 $\mathrm{K}^{+}$channel blocker. Notably, blockage of type $\mathrm{M} \mathrm{K}^{+}$current with XE-991, which may be active at resting membrane potential (Wladyka and Kunze, 2006), 

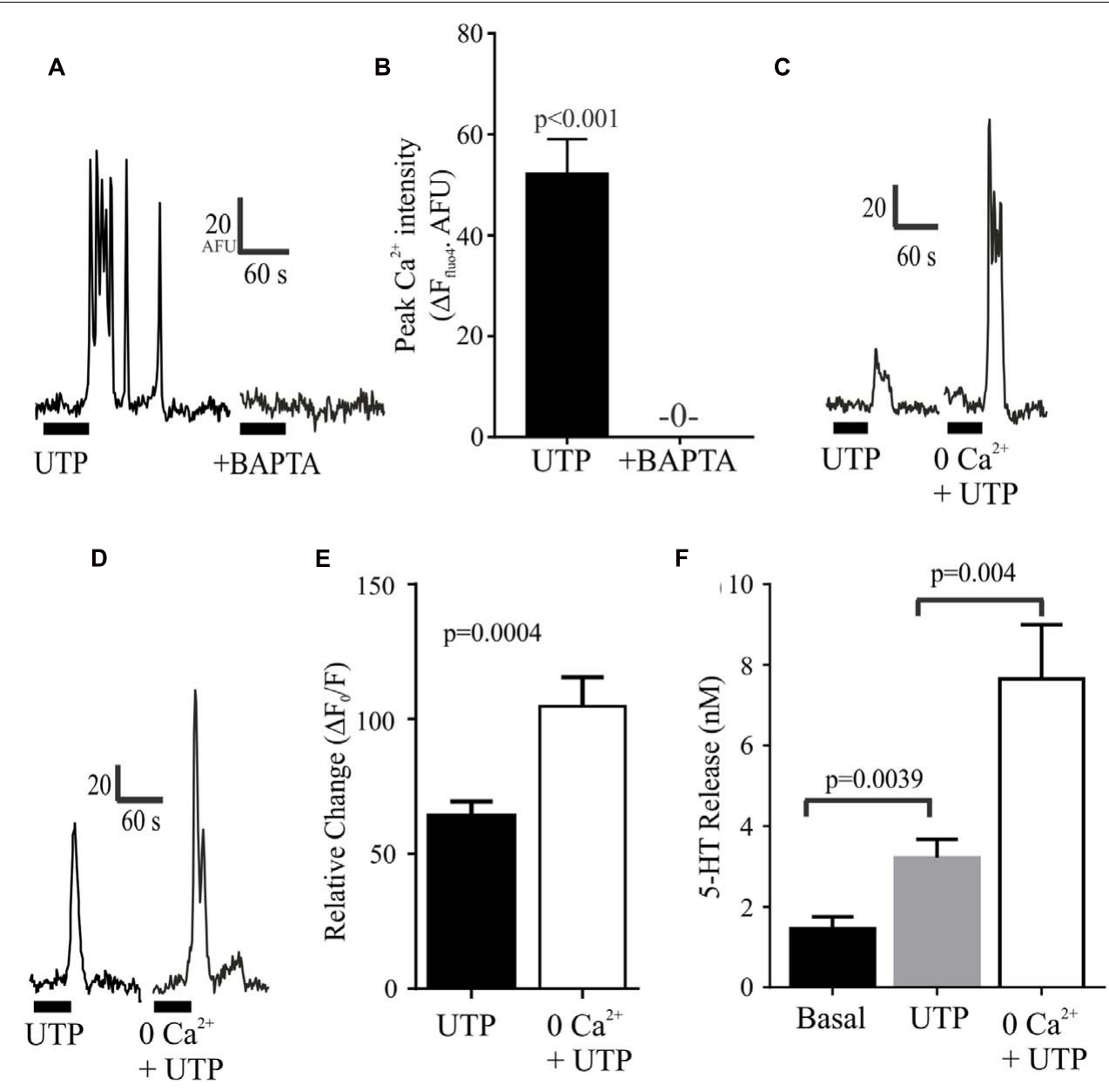

FIGURE 9 | Depletion of intracellular or extracellular $\mathrm{Ca}^{2+}$ has different effects on UTP $\mathrm{Ca}^{2+}$ responses. (A,B) Chelating intracellular free Ca ${ }^{2+}$ levels with BAPTA-AM $(50 \mu \mathrm{M})$ abolishes UTP-induced $\mathrm{Ca}^{2+}$ transients. (C-E) $\mathrm{Ca}^{2+}-$ free buffer $\left(0.0 \mathrm{Ca}^{2+}+\right.$ EGTA) augments peak Ca ${ }^{2+}$ responses induced by UTP in a subset of cells. (F) In the absence of extracellular $\mathrm{Ca}^{2+}\left(\mathrm{Ca}^{2+}\right.$-free buffer), UTP is more effective in stimulating 5 - $\mathrm{HT}$ release from BON cells ( $N=12$ cultures).

mimicked UTP actions by causing $\mathrm{V}_{\mathrm{m}}$ depolarization, and increased $\mathrm{R}_{\mathrm{i}}$ (Figures 11C,D,F, $5.13 \pm 0.64 \mathrm{mV}$ depolarization for UTP versus $6.08 \pm 0.82 \mathrm{mV}$ depolarization for XE-991 alone). Furthermore, pre-incubation of BON cells with XE-991 significantly reduced the number of cells responsive to the application of UTP (8 out of 15 cells respond to UTP; 2 of 17 cells respond to UTP after XE-991 treatment, $p=0.02$ ) (Figures 11C,F).

$\mathrm{K}_{\mathrm{v}} 7$ potassium channel subunits can contribute to the generation of a voltage dependent outward current that does not inactivate in the presence of depolarizing pulses and they may participate actively in the control of the membrane potential (Schroeder et al., 2000). Therefore, we looked to further confirm the modulation of this conductance by UTP. We isolated voltage activated potassium currents, total $\mathrm{K}_{\mathrm{v}}$ currents, and tested whether or not there was a modulation by UTP. As expected, acute UTP application $(100 \mu \mathrm{M})$ reduced the K-type component ( $\mathrm{I}_{\mathrm{K}}$, Figure 12A, $p<0.0001, n=8$ ) without affecting the A-type outward potassium currents $\left(\mathrm{I}_{\mathrm{A}}\right.$, Figure 12B). A robust reduction of $I_{K}$ currents was observed after incubation of the cells with the potassium channels blocker XE-991, generally used for selective blockage of subunits $\mathrm{K}_{\mathrm{V}}$ 7.1/7.2/7.3 (Figure 12C, $p<0.0001, n=3$ ). However, UTP modulation of $\mathrm{I}_{\mathrm{K}}$ currents persisted in the presence of XE-991 (Figure 12C, $p<0.0001$, $n=5$ ). These results suggest that besides the modulation of the potassium conductance involved in membrane potential control (i.e., carried by $\mathrm{K}_{\mathrm{v}} 7.1 / 7.2 / 7.3$ subunits), UTP may modulate an additional potassium conductance. The identity of this pathway/conductance was not considered further in our study. However, M-type currents seem to have small magnitude in BON cells, and we were unable to isolate them by voltage-clamp, and therefore, we were unable to further corroborate our findings on $\mathrm{V}_{\mathrm{m}}$ with the $\mathrm{Kv} 7.1$ antagonist XE-991. Therefore, it remains unresolved whether M-currents are being modulated by UTP. Furthermore, the effect of UTP on $\mathrm{I}_{\mathrm{K}}$ does not account for its effects on $\mathrm{V}_{\mathrm{m}}$ depolarization, since UTP reduced current at $+50 \mathrm{mV}$ and did not affect $\mathrm{K}^{+}$currents at potentials close to the resting potential. We considered the possibility that more than one potassium conductance is being modulated by UTP. 


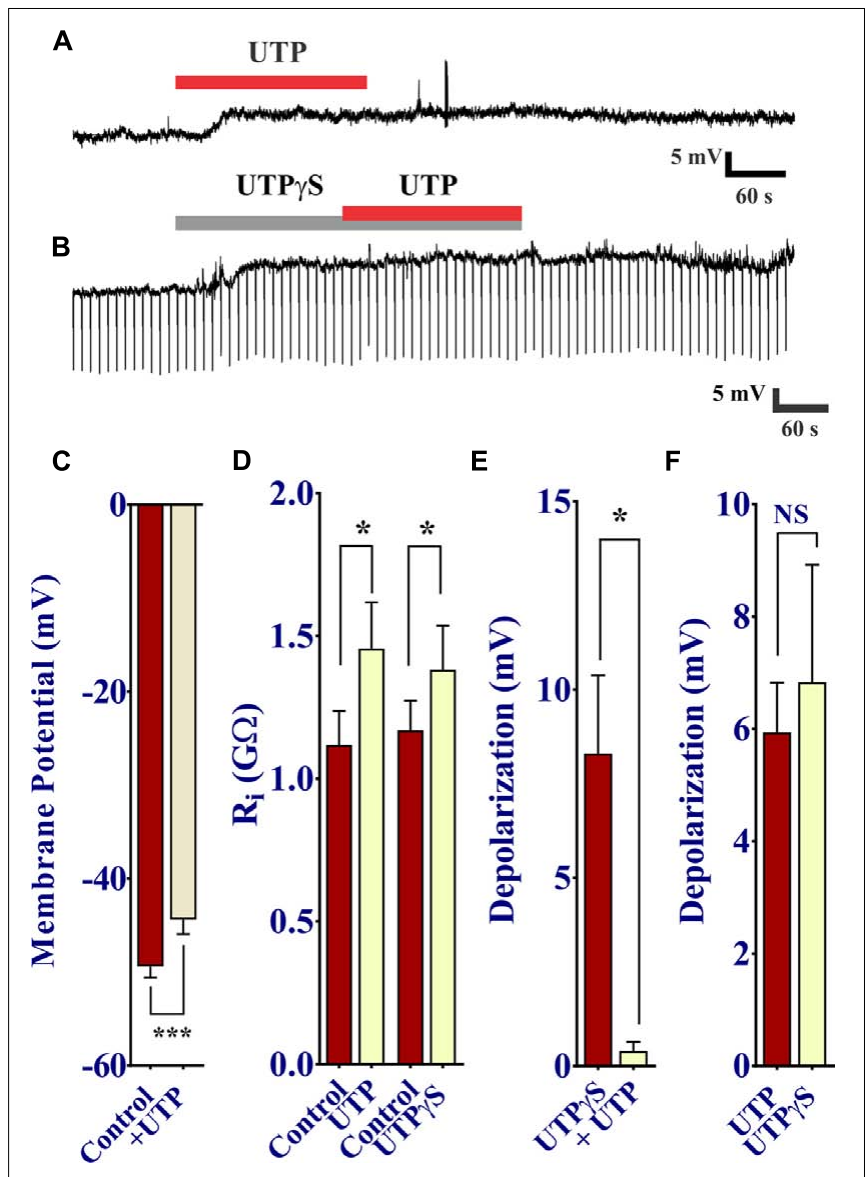

FIGURE 10 | UTP depolarizes the membrane potential in human BON. (A) Acute application of $100 \mu \mathrm{M}$ UTP causes $V_{m}$ depolarization (upper trace, representative response), associated with an increase in cell input resistance $\left(R_{i}\right.$; (B), lower panel; $1.12 \pm 0.12 \mathrm{G} \Omega$ for control vs. $1.46 \pm 0.16 \mathrm{G} \Omega$ for UTP, $p=0.01, n=7 ; 1.12 \pm 0.10 \mathrm{G} \Omega$ for control vs. $1.38 \pm 0.15 \mathrm{G} \Omega$ for UTP $\gamma \mathrm{S}$, $p=0.038, n=6)$. UTP $\gamma S$ mimicked UTP evoked $V_{m}$ depolarization and if UTP $\gamma S$ is used to depolarize the cell, UTP no longer has any effect (lower trace). (C) UTP causes a significant depolarization of the membrane potential. (D) UTP or UTP $\gamma \mathrm{S}$ causes a modest but significant increase in cell input resistance. Bars, SEM. Asterisk denotes statistical significance when analyzed with student's $t$-test. (E) UTP $\gamma S$ induced $V_{m}$ depolarization prevents the response to subsequent co-application of UTP $(8.30 \pm 2.08 \mathrm{mV}$ for UTP $\gamma \mathrm{S}$ and $0.40 \pm 0.24 \mathrm{mV}$ for UTP, $p=0.0165, n=5)$. (F) UTP and UTP $\gamma S$ evoked a similar $V_{m}$ depolarization $(p>0.05$, NS; $5.94 \pm 0.88 \mathrm{mV}$ for UTP and $6.83 \pm 2.09 \mathrm{mV}$ for UTP $\gamma \mathrm{S}, n=17$ and 6 , respectively).

\section{UTP Activates VOCC (I $\mathrm{Ca}_{\mathrm{a}}$ Currents)}

Previous reports had demonstrated that $\mathrm{Ca}^{2+}$ conductance via voltage-operated $\mathrm{Ca}^{2+}$ channels (VOCCs) could induce an increase in 5-HT release (Lomax et al., 1999). Our results indicated that the VOCC blocker $\mathrm{La}^{3+}$ abolished the UTP response observed with $\mathrm{Ca}^{2+}$ imaging, although an L-type $\mathrm{Ca}^{2+}$ channel blocker nicardipine did not inhibit the UTP response. Therefore, we employed the whole-cell patch clamp technique on BON cells to further assess VOCC activity in response to UTP. $\mathrm{Ba}^{2+}$ was used as a charge carrier in a standard solution free of $\mathrm{Na}^{+}$, and $\mathrm{K}^{+}$channels were blocked by addition of TEA/4-AP and Cs in the electrode solution. After a $10 \mathrm{~min}$

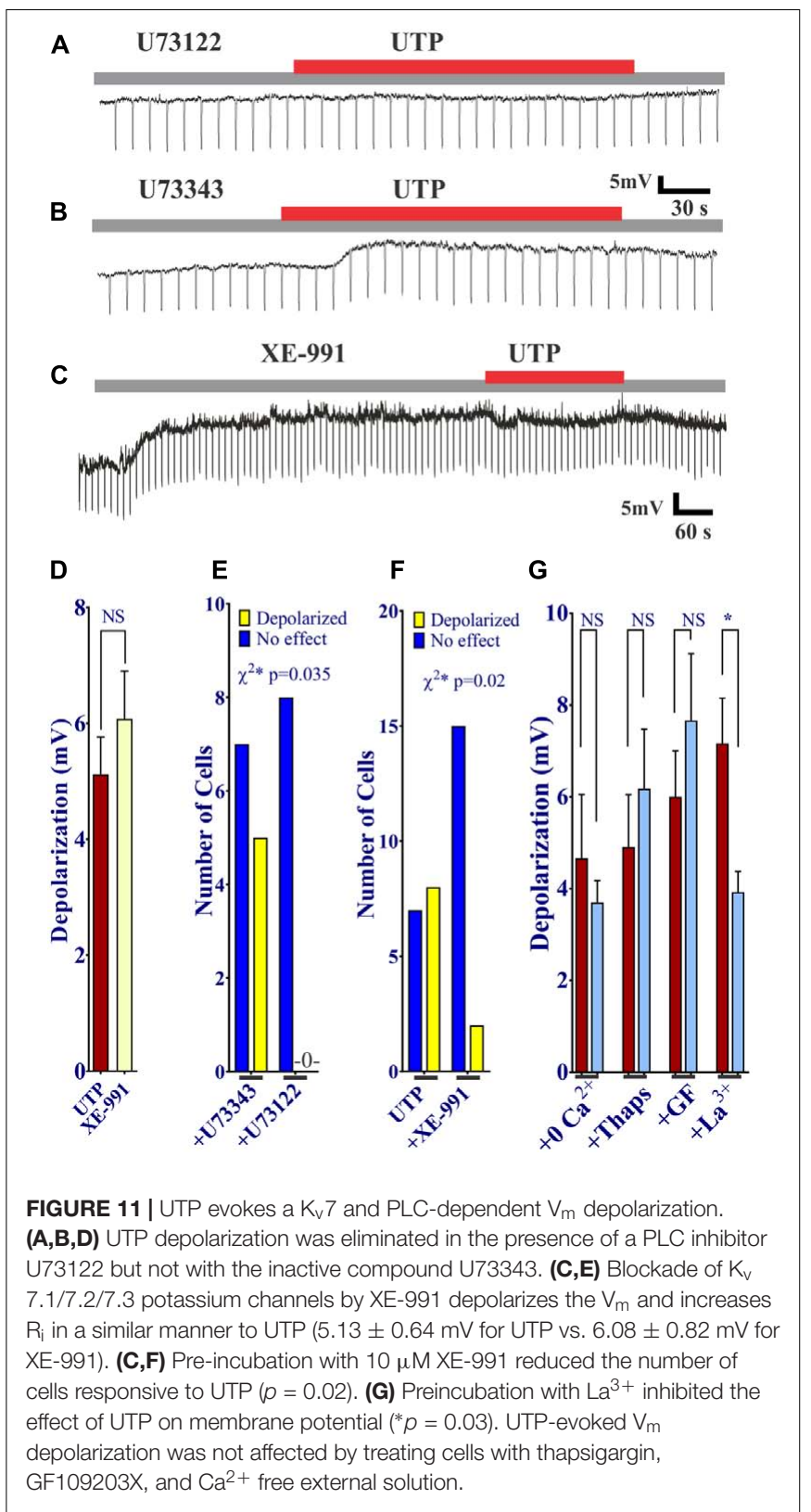

stabilization period and bath solutions exchange, $\mathrm{Ca}^{2+}$ channels were voltage stimulated and evoked $\mathrm{Ba}^{2+}$ currents recorded before and after $3 \mathrm{~min}$ of UTP, UTP $\gamma \mathrm{S}$ or UDP application. UTP significantly augmented the current density carried by VOCC (Figure 13A, at $\mathrm{V}_{\mathrm{m}}$ of $-20 \mathrm{mV}, 0-40 \mathrm{mV}, p<0.0001 ; n=10$ ). The effect of UTP was reversible with a $3 \mathrm{~min}$ washout (not shown). UTP treated cells, also had an evident persistence of the currents during the application of voltage steps (Figure 13E). Interestingly, although not significant, UTP caused a shift in the VOCC voltage-dependence (Figure 13A,$-20.33 \pm 5.61 \mathrm{mV}$ control vs. $-15.35 \pm 8.05 \mathrm{mV}$ UTP, $n=10, p>0.05$ ).

The $\mathrm{P}_{2} \mathrm{Y}_{2 / 4}$ agonist UTP $\gamma \mathrm{S}$ also augmented the currents carried by VOCC (Figure 13B, at $\mathrm{V}_{\mathrm{m}}$ of $-30-20 \mathrm{mV}, p<0.0001$; $n=6$ ); however, there was not any effect on the voltage 

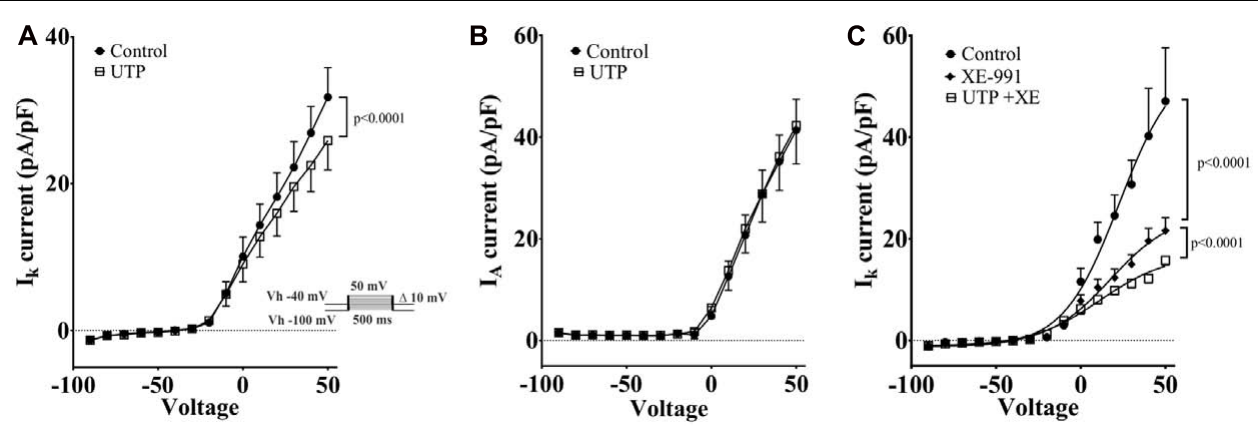

FIGURE 12 | Cells treated with UTP exhibit a decrease in $I_{K}$ potassium currents. Graphs show the mean $I_{K}$ and $I_{A}$ currents obtained by measuring the peak of each voltage step which were dissected by manipulating the holding potential. The $I_{A}$ currents were determined by subtracting $I_{K}$ currents from $I_{T o t}$ currents. Insert shows the voltage steps protocol used to achieve voltage dependent potassium currents, $V_{h}$ indicates holding potential. (A) Summary of data showing a decrease in $I_{k}$ potassium currents initiated by UTP $(p<0.0001, n=8)$. (B) $\mathrm{I}_{\mathrm{A}}$ potassium currents were not significantly affected by UTP. (C) Shows a summary of results presenting a reduction in the evoked $I_{K}$ currents $(p<0.0001, n=3-5)$ in the presence of XE-991 alone and in combination with UTP. Symbols represent mean \pm SEM.

dependency (Figure 13, control: $-21.94 \pm 3.70 \mathrm{mV}$ versus UTP $\gamma$ S: $-21.81 \pm 3.595 \mathrm{mV}, n=6$ ) and notably, cells treated with UTP $\gamma S$ did not show evidence of any change in the persistence of currents during stimulation with voltage steps as shown to occur with UTP treatment (Figure 13E). Interestingly, preferential $\mathrm{P}_{2} \mathrm{Y}_{6}$ stimulation by application of UDP, caused a statistically significant shift to the right $(5.7 \mathrm{mV})$ in the VOCC voltage dependence (Figure 13C, control: $-13.57 \pm 4.22 \mathrm{mV}$ versus UDP: $-7.85 \pm 7.99 \mathrm{mV} ; n=8, p=0.0028)$, and contrary to $\mathrm{P}_{2} \mathrm{Y}_{4}$ activation with $\mathrm{UTP} \gamma \mathrm{S}$, there was not a significant change in the current density (Figure 13B, $n=8$, $p>0.05)$. It is essential to note that no further analysis with a $\mathrm{P}_{2} \mathrm{Y}_{2}$ specific agonist was considered necessary as $\mathrm{Ca}^{2+}$ imaging studies ruled out any significant involvement of the receptor.

To determine whether or not the increase in VOCC conductance evoked by UTP was linked to the changes in MP, we performed a series of experiments in $\mathrm{Ca}^{2+}$ free external solution, and pre-incubating cells with $\mathrm{La}^{3+}$, a general blocker of VOCC. The latter intervention had an effect on the UTPevoked $\mathrm{V}_{\mathrm{m}}$ depolarization. $\mathrm{V}_{\mathrm{m}}$ depolarization for UTP in normal $\mathrm{Ca}^{2+}$ solution was $4.67 \pm 1.38 \mathrm{mV}(n=9)$ and $3.70 \pm 0.47 \mathrm{mV}$ $(n=10)$ for UTP in $\mathrm{Ca}^{2+}$ free medium $(p>0.05)$. For cells treated with $\mathrm{La}^{3+}, \mathrm{V}_{\mathrm{m}}$ depolarization was $7.33 \pm 1.05 \mathrm{mV}$ for UTP $(n=12)$ and $3.93 \pm 0.44 \mathrm{mV}$ for UTP $+\mathrm{La}^{3+}$ ( $n=7, p=0.03$ ) (Figure 11G). Furthermore, UTP-evoked $\mathrm{V}_{\mathrm{m}}$ depolarization was not dependent of intracellular $\mathrm{Ca}^{2+}$ increase from intracellular stores, since, pre-incubation with a PKC inhibitor GF109203X (Toullec et al., 1991) and thapsigargin (Thaps) to deplete intracellular $\mathrm{Ca}^{2+}$ stores via activation of the sarco-endoplasmic reticulum $\mathrm{Ca}^{2+}$-ATPase (SERCA) were also not effective in reducing UTP-evoked $\mathrm{V}_{\mathrm{m}}$ depolarization (Figure 11G, $4.91 \pm 1.14 \mathrm{mV}$ for UTP, $n=11 ; 6.18 \pm 1.30 \mathrm{mV}$ for UTP+Thaps, $n=11, p>0.05$ ).

These results suggest UTP activates simultaneously several parallel pathways that contribute to the activation of P2Y receptors. Whether or not UTP modulation of $\mathrm{K}^{+}$conductance and VOCCs contribute to the modulation of 5-HT release is still to be confirmed.

\section{DISCUSSION}

ATP (or ADP) modulates mechanically-evoked 5-HT release via autocrine activation of stimulatory $\mathrm{P}_{2} \mathrm{Y}_{1}$, inhibitory $\mathrm{P} 2 \mathrm{Y}_{12}$ purinergic pathways and ATP-gated $\mathrm{P}_{2} \mathrm{X}_{3}$-channels (LiñánRico et al., 2013). The current study expands our knowledge of purinergic signaling mechanisms by identifying uridine nucleotide receptors that are activated by UTP or UDP to induce a rise in intracellular free $\mathrm{Ca}^{2+}$ levels $\left\{\left[\mathrm{Ca}^{2+}\right]_{\mathrm{i}}\right\}, \mathrm{Ca}^{2+}$ oscillations, $\mathrm{V}_{\mathrm{m}}$ depolarization and 5 -HT release. These receptors are novel targets in EC cells for chemosensory regulation of gut reflexes.

\section{Role of $\mathrm{P}_{4}, \mathrm{P}_{4} \mathrm{Y}_{6}, \mathrm{P}_{2} \mathrm{Y}_{2}$, Receptors in $\mathrm{Ca}^{2+}$ Signaling}

UTP elicits a biphasic response in EC cells suggesting more than one receptor. At lower concentrations $\left(\mathrm{EC}_{50}=11.4 \mu \mathrm{M}\right)$, UTP activates both $\mathrm{P}_{2} \mathrm{Y}_{4}$ and $\mathrm{P}_{2} \mathrm{Y}_{6}$ Rs (Abbracchio et al., 2006). The receptor activated at high concentrations is unknown. Functional $\mathrm{P}_{2} \mathrm{Y}_{2}$ receptors $\left(\mathrm{P} 2 \mathrm{Y}_{2} \mathrm{R}, \mathrm{MRS} 2768\right)$ are rare in $\mathrm{BON}(\mathrm{EC})$ cells, and are not involved in $\mathrm{Ca}^{2+}$ oscillations. UTP $\left(\mathrm{P}_{2,4,6}\right), \mathrm{UTP} \gamma \mathrm{S}$ $\left(\mathrm{P} 2 \mathrm{Y}_{2,4}\right)$, UDP $\left(\mathrm{P}_{2} \mathrm{Y}_{6}\right)$ or ATP induced $\mathrm{Ca}^{2+}$ oscillations (or single $\mathrm{Ca}^{2+}$ transients) in $\mathrm{BON}$.

Overall, pharmacological and molecular analysis indicates that the predominant site is the $\mathrm{P}_{2} \mathrm{Y}_{4} \mathrm{R}$ in $\mathrm{BON}$. However, expression of $\mathrm{P} 2 \mathrm{Y}_{4} \mathrm{R}$ and $\mathrm{P} 2 \mathrm{Y}_{6} \mathrm{R}$ is passage-dependent and therefore, definitive identification of the relative importance of these receptors awaits further study in freshly isolated human EC from surgical specimens that express both receptors.

Cells responded in the order of UTP/ATP $>$ UTP $\gamma S$ $\left(\mathrm{P}_{2} \mathrm{Y}_{2 / 4}\right)>\mathrm{UDP}>>\operatorname{MRS} 2768\left(\mathrm{P} 2 \mathrm{Y}_{2}\right), \operatorname{BzATP}\left(\mathrm{P}_{2} \mathrm{X}_{7}\right)$, $\alpha, \beta$-MeATP $\left(\mathrm{P} 2 \mathrm{X}_{1,2 / 3,3}\right)>\operatorname{MRS} 2365\left(\mathrm{P} 2 \mathrm{Y}_{1}\right), \operatorname{MRS} 2690\left(\mathrm{P}_{14} \mathrm{Y}_{14}\right)$, NF546 (P2Y $\left.{ }_{11}\right)$. P2X $1,2 / 3,3$ R, P2X 7 R, P2Y ${ }_{1}$ R, P2 ${ }_{11}$ R and P2 ${ }_{14} \mathrm{R}$ play a minor role in chemosensory signaling. Agonist responses are consistent with the presence of multiple functional purinergic receptors. First, agonists with selectivity for different receptors had no effect, induced only a monophasic $\mathrm{Ca}^{2+}$ response, or also had oscillatory responses. Second, different proportions of cells 

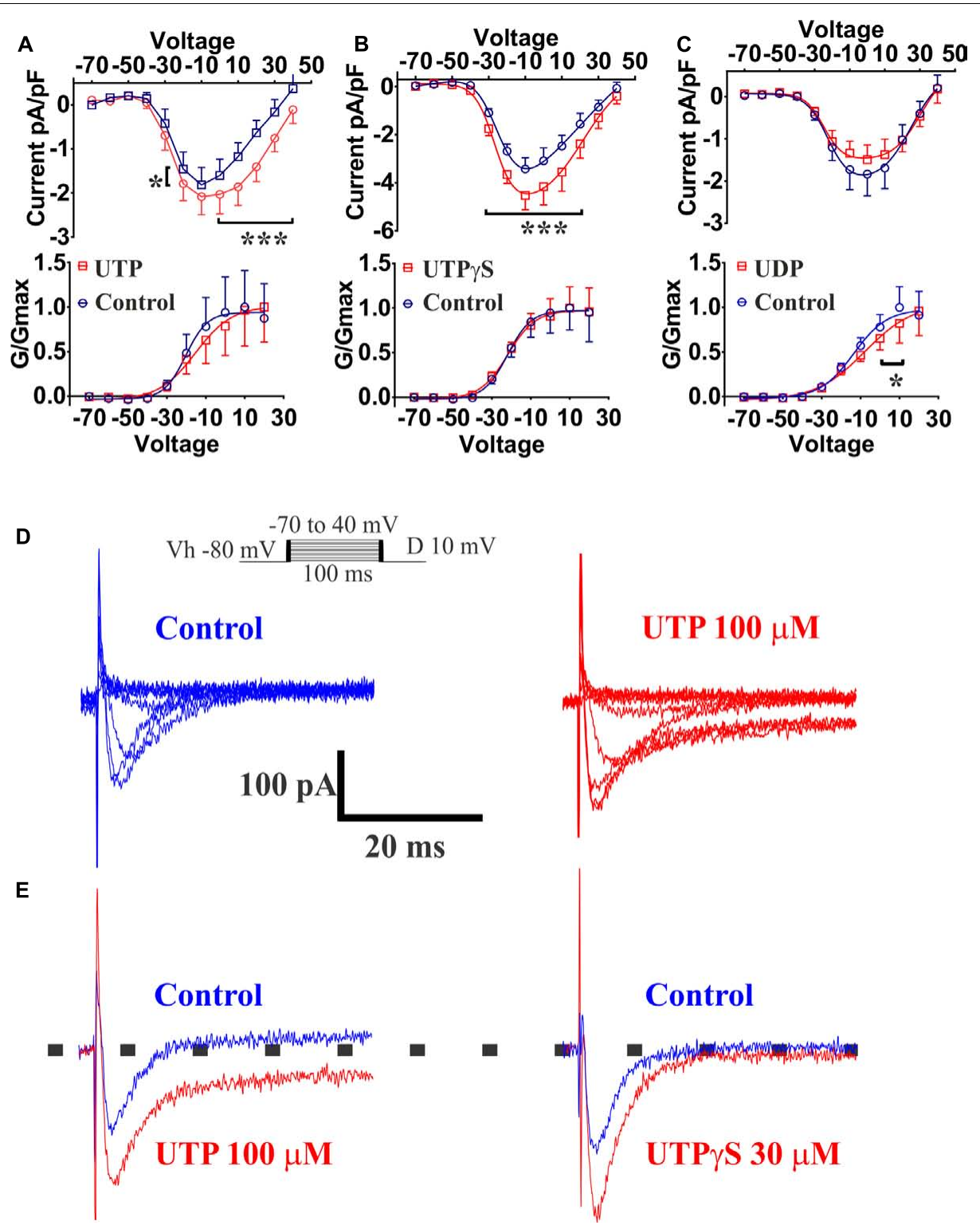

FIGURE 13 | UTP increased currents carried by VOCC in a BON cell model of EC. Acute application of $100 \mu \mathrm{M}$ UTP increased the magnitude of the currents carried by VOCCs while shifting the voltage dependence to the right. Acute application of UTP $\gamma S$ increased VOCC conductance (Ica) without affecting its voltage dependency. (A-C) Effect of bath application of UTP, UTP $\gamma$ S and UDP, respectively, are summarized as current/voltage curves (top panels). There was an increase in the $\mathrm{I}_{\mathrm{ca}}$ currents after application of UTP (at $\mathrm{V}_{\mathrm{m}}$ of $-20,0$, to $40 \mathrm{mV}, p<0.0001, n=10$ ) and UTP $\mathrm{S}$ (at Vm of -30 to $20, p<0.0001, n=6$ ) but not in the presence of UDP ( $n=8, p>0.05)$. Bottom panels show voltage-response curves plotted as normalized conductance $\left(G / G_{\max }\right)$ against voltage ( $\left.\mathrm{mV}\right)$, and adjusted by a Boltzmann dose-response equation. There was $\sim 5 \mathrm{mV}$ shift in the voltage dependence when UTP was applied $(-20.33 \pm 5.611 \mathrm{mV}$ control vs. $-15.35 \pm 8.045 \mathrm{mV}$ UTP, $n=10, p=0.1842)$ and a $5.7 \mathrm{mV}$ shift when UDP was applied (-13.57 $\pm 4.22 \mathrm{mV}$ control vs. $-7.85 \pm 7.99 \mathrm{mV}$ UDP, $n=8, p=0.0028)$. There was not any difference in voltage dependency with UTP $\gamma \mathrm{S}(-21.94 \pm 3.70 \mathrm{mV}$ control vs. $-21.81 \pm 3.595 \mathrm{mV}$ UTP $\gamma \mathrm{S}, n=6)$. (D) Representative current-trace for one cell before and after UTP stimulation (top panels up to $0 \mathrm{mV}$ ). (E) Representative control traces (blue) and after application (red) of UTP (left) and UTP $\gamma \mathrm{S}$ (right). Persistence in the $I_{\mathrm{ca}}$ currents during the voltage steps was observed after stimulating the cells with UTP but not after UTP $\gamma \mathrm{S}$. Cells were depolarized from a holding potential of $-80 \mathrm{mV}$ with $10 \mathrm{mV}$ increasing voltage steps, which ranged from -70 to $40 \mathrm{mV}$ with a duration of $100 \mathrm{~ms}$ (insert panel in D). Current amplitude was normalized to individual cell capacitance and showed as pA per pF. Data are plotted as mean \pm SEM. Data were analyzed by two-way ANOVA, and statistical significances are denoted with asterisks $(* * * p<0.001 ; * p<0.05)$.

activated by UTP and ATP also responded to UTP $\gamma \mathrm{S}$ ( $50 \%$ cells), UDP $(30 \%)$, UTP $\gamma$ S/UDP (14\%) or MRS2768 $(<3 \%)$. Third, the profile of activity in response to consecutive applications of UTP, UTP $\gamma$ S, UDP (and ATP) is consistent with subsets of EC cells that express $\mathrm{P}_{2} \mathrm{Y}_{4}, \mathrm{P}_{2} \mathrm{Y}_{6}$ or both $\mathrm{P}_{2} \mathrm{Y}_{4}$ and $\mathrm{P}_{2} \mathrm{Y}_{6}$. In cells responding to UTP and ATP but no other agonists, different receptors are involved. ATP itself lucks intrinsic activity at human $\mathrm{P}_{2} \mathrm{Y}_{4} \mathrm{R}$ (Kennedy et al., 2000). $\mathrm{P}_{2} \mathrm{Y}_{13}, \mathrm{P} 2 \mathrm{X}_{4}, \mathrm{P}_{2} \mathrm{X}_{5}$ or $\mathrm{P} 2 \mathrm{X}_{6}$ are 
potential candidates for ATP (not UTP) responses (Communi et al., 1999; Zhang et al., 2002; Abbracchio et al., 2006; Kügelgen, 2006; Kügelgen and Bonn, 2008). UTP does not activate hP2 $\mathrm{Y}_{11} \mathrm{R}$ (Morrow et al., 2014) and P2Y 11 effects to NF546 (Meis et al., 2010) in BON were rare. The $\mathrm{hP}_{2} \mathrm{Y}_{4} \mathrm{R}$ forms stable dimers and transfected $\mathrm{P}_{2} \mathrm{Y}_{4} \mathrm{R}$ and $\mathrm{P}_{2} \mathrm{Y}_{6} \mathrm{R}$ proteins can associate with P2Y1,2,4,6,11 receptors (D'Ambrosi et al., 2006, 2007; Bilbao et al., 2012). Therefore, specific dimers could be responding to UTP and not UTP $\gamma$ S or UDP. This could also contribute to the biphasic nature of UTP responses at low or high micromolar levels.

Overall, the pharmacological data clearly show that subpopulations of cells exhibit responses to different sets of agonists. Subpopulations of responses suggest that UTP, ATP and UDP can activate different combinations of purinergic receptors in different cells, and therefore, subtypes of EC cells can be distinguished by their functional expression of purinergic receptors, including $\mathrm{P}_{2} \mathrm{Y}_{4}, \mathrm{P}_{2} \mathrm{Y}_{6}, \mathrm{P}_{2} \mathrm{Y}_{2}, \mathrm{P}_{2} \mathrm{Y}_{4} / \mathrm{P}_{2} \mathrm{Y}_{6}$, and other receptors not yet identified that respond to UTP and ATP.

\section{Post-receptor $\mathrm{Ca}^{2+}$ Signaling Pathways}

Chelating intracellular free $\mathrm{Ca}^{2+}$ levels prevented UTP $\mathrm{Ca}^{2+}$ responses indicating that the response is due to a rise in $\left[\mathrm{Ca}^{2+}\right]_{\mathrm{i}} \cdot \mathrm{Ca}^{2+}$ influx does not contribute to UTP-induced $\mathrm{Ca}^{2+}$ responses (Nikodijevic et al., 1994), and suggests that the response may be a result of mobilization of $\mathrm{Ca}^{2+}$ from intracellular stores. $\mathrm{Ca}^{2+}$ free buffer augmented UTP-induced rise in $\left[\mathrm{Ca}^{2+}\right]_{\mathrm{i}}$ and 5-HT release, suggesting $\mathrm{Ca}^{2+}$ influx is an inhibitory modulatory mechanism in UTP responses. This was an unexpected finding and the mechanism involved remains unknown.

$\mathrm{La}^{3+}$ is an inhibitor of transmembrane $\mathrm{Ca}^{2+}$ fluxes and a blocker of VOCCs (Block et al., 1998) and NSCC (Pena and Ordaz, 2008). In BON, $\mathrm{La}^{3+}$ was shown to block capsaicininduced $\mathrm{Ca}^{2+}$ responses (Mergler et al., 2012). In our study, $\mathrm{La}^{3+}$ could prevent the UTP-induced $\mathrm{Ca}^{2+}$ response suggesting that a NSCC or $\mathrm{Ca}^{2+}$ current through VOCCs is essential for the response. Nicardipine sensitive L-type VOCCs are not involved, although UTP activates other VOCCs (i.e., $\mathrm{I}_{\mathrm{Ca}}$ currents).

The PLC inhibitor U73122 or an $\mathrm{IP}_{3} \mathrm{R}$ inhibitor $2 \mathrm{APB}$ could inhibit or abolish UTP responses in BON, indicating that the $\mathrm{G}_{\mathrm{q}} / \mathrm{PLC} / \mathrm{IP}_{3}-\mathrm{Ca}^{2+}$ signaling pathway is essential in triggering UTP $\mathrm{Ca}^{2+}$ responses. MRS1845 blockade of storeoperated $\mathrm{Ca}^{2+}$ entry (Harper et al., 2003) had no effect. $2 \mathrm{APB}$ could also modulate TRP channels (Alkhani et al., 2014), but a TRPC channel blocker SKF96365 that also inhibits storeoperated $\mathrm{Ca}^{2+}$ entry (SOCE) had no effect. PLC activation in non-excitable cells can cause release of $\mathrm{Ca}^{2+}$ from intracellular stores and activation of $\mathrm{Ca}^{2+}$ influx by means of $\mathrm{Ca}^{2+}$ releaseactivated channels (CRAC). The $\mathrm{I}_{\mathrm{CRAC}}$ channel is not involved since SKF95365 had no effect on UTP responses (Kaznacheyeva et al., 2001). Other mechanisms were also excluded, including ryanodine-sensitive $\mathrm{Ca}^{2+}$ pools and Kinases (PI3K, PKC, and SRC-K). The SERCA pump inhibitor thapsigargin (Tuluc et al., 2005) abolished UTP $\mathrm{Ca}^{2+}$ responses, indicating that it is an essential mechanism.

\section{UTP - Induced $V_{m}$ Depolarization, $I_{K}$ and $I_{A}$ Currents}

UTP or UTP $\gamma \mathrm{S}$ caused $\mathrm{V}_{\mathrm{m}}$ depolarization in $50 \%$ of cells associated with increase in cell Ri, suggesting a closure of $\mathrm{K}^{+}$channels. UTP did not affect the $\mathrm{I}_{\mathrm{A}}$ current. Potassium channels, including $K_{v} 7.1$ have been implicated in regulation of secretion (Ullich et al., 2005; Yamagata et al., 2011). UTP inhibits ATP sensitive and voltage-dependent $\mathrm{K}^{+}$currents $\left(\mathrm{I}_{\mathrm{K}}\right.$, Welsh and Brayden, 2001). A $\mathrm{K}_{\mathrm{v}}$ 7.1/7.2/7.3 $\mathrm{K}^{+}$channel blocker XE-991 induced membrane depolarization of BON, mimicking the UTP-induced membrane depolarization and blocked UTP responses, implying that closure of $\mathrm{IK}_{\mathrm{v}}$ 7.1/7.2/7.3 channels is linked to UTP depolarization. Desensitization to UTP $\gamma \mathrm{S}$ prevents UTP responses, suggesting involvement of a $\mathrm{P}_{2} \mathrm{Y}_{4} \mathrm{R}$. Findings with GF109203X or thapsigargin indicate that PKC or the SERCA mechanism is not involved in slow membrane depolarization. Overall, PLC inhibition blocked depolarization and $\mathrm{Ca}^{2+}$ responses to UTP, whereas thapsigargin or zero $\mathrm{Ca}^{2+}$ buffer had no effect on depolarization, indicating that $\mathrm{V}_{\mathrm{m}}$ depolarization is not linked to $\mathrm{Ca}^{2+}$ responses. $\mathrm{La}^{3+}$ blocked UTP-evoked $V_{m}$ depolarization, whereas zero $\mathrm{Ca}^{2+}$ buffer had no effect. This is explained by direct block of $\mathrm{K}^{+}$conductance (Type-M) by La ${ }^{3+}$ (Hirasawa et al., 2000).

When $I_{K}$ currents were isolated, UTP reduced the overall prominent $\mathrm{I}_{\mathrm{K}}$ currents. However, although a major component of the $\mathrm{I}_{\mathrm{K}}$ currents could be blocked by a $\mathrm{K}_{\mathrm{v}}$ 7.1,7.2,7.3 channel inhibitor XE-991 alone (Yeung and Greenwood, 2005), it did not block the effect of UTP on $I_{K}$ currents, indicating that UTP can inhibit an $\mathrm{I}_{\mathrm{K}}$ current that is insensitive to XE-991. Its identity remains unknown. XE-991 inhibits $\mathrm{K}_{\mathrm{v}} 7$ channels, but at the $10 \mu \mathrm{M}$ concentration used, it may inhibit $\mathrm{K}_{\mathrm{v}} 1.2 / \mathrm{K}_{\mathrm{v}} 1.5$ and $\mathrm{K}_{\mathrm{v}} 2.1 / \mathrm{K}_{\mathrm{v}} 9.3$ channels (Zhong et al., 2010). However, at resting membrane potential of -50 to $-60 \mathrm{mV}$ ( $-54 \mathrm{mV}$ for BON), $\mathrm{K}_{\mathrm{v}} 7$ channels have an appreciable open probability that can be inhibited by XE-991 (Brown and Passmore, 2009; Mani et al., 2011). It has been shown $K_{v} 7.2 / 7.3$ channels are modulated by PLC/PIP $/ \mathrm{IP}_{3}$ in other cells. In fact, $\mathrm{K}_{\mathrm{v}} 7$ channels seem to require PIP2 to maintain open state (Zhang et al., 2003) and are negatively modulated by PIP2 membrane depletion (Hughes et al., 2007; Brown and Passmore, 2009; Falkenburger et al., 2010, 2013). Therefore, we suggest that UTP activation of PLC signaling leads to PIP2 depletion (a substrate for $\mathrm{IP}_{3}$ formation) to inactivate the $\mathrm{K}_{\mathrm{v}} 7$ channels, and closure of the channels leads to $V_{m}$ depolarization. The effect of UTP on $I_{K}$ currents seems independent of $V_{m}$ depolarization. Specifically, the effect of UTP on $\mathrm{K}_{\mathrm{v}}$ does not account for its effects on $\mathrm{V}_{\mathrm{m}}$ depolarization, since UTP reduced current at $+50 \mathrm{mV}$ and did not affect $\mathrm{K}^{+}$currents at potentials close to the resting potential. We could not isolate other $\mathrm{K}_{\mathrm{v}}$ currents (i.e., M-currents) in BON to test with UTP.

\section{Voltage-Dependent $\mathrm{Ca}^{2+}$ Currents ( $\left.{ }_{\mathrm{Ca}}\right)$}

The fact that UTP and UTP $\gamma S$ but not UDP induced an increase of voltage-dependent $\mathrm{Ca}^{2+}$ currents $\left(\mathrm{I}_{\mathrm{Ca}}\right.$ ) in $\mathrm{BON}$ suggests involvement of a $\mathrm{P}_{2} \mathrm{Y}_{4} \mathrm{R}$ in modulating VOCC. However, UTP-modulation of $\mathrm{I}_{\mathrm{Ca}}$ was not linked to UTP-induced $\mathrm{V}_{\mathrm{m}}$ 


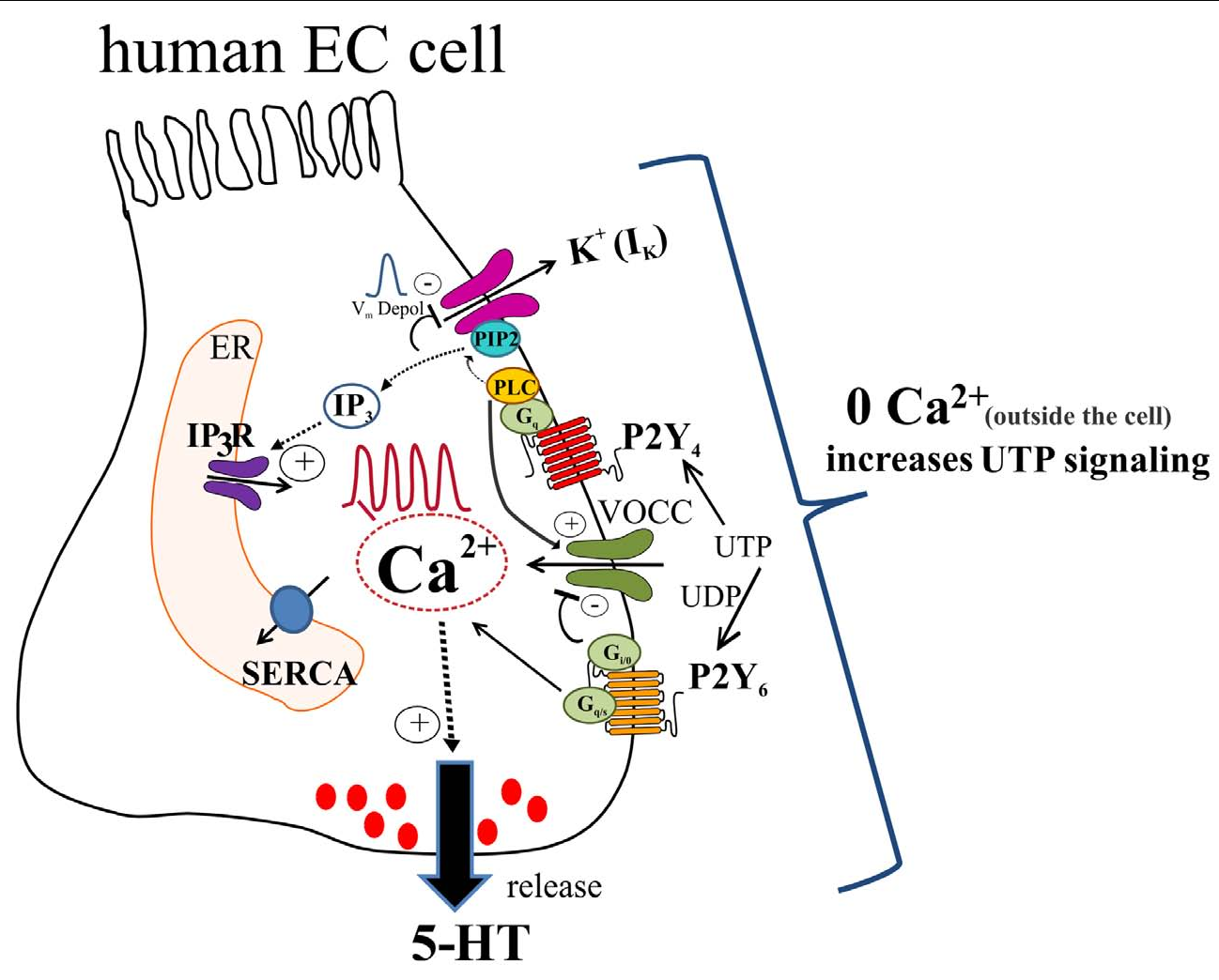

FIGURE 14 | Working hypothesis of uridine nucleotide signaling in human EC cells lining the Gl mucosa. UTP (or UDP) activate P2Y 4 and P2Y receptors in EC cells to elevate intracellular free $\mathrm{Ca}^{2+}$ levels $\left(\left[\mathrm{Ca}^{2+}\right]_{\mathrm{i}}\right)$ and generate $\mathrm{Ca}^{2+}$ oscillations or monophasic $\mathrm{Ca}^{2+}$ transients, and cause membrane depolarization. UTP acts via $\mathrm{P} \mathrm{Y}_{4}$ to stimulate a Gq/PLC-PIP2-IP3-IP3R/SERCA signaling pathway to elevate $\left[\mathrm{Ca}^{2+}\right]_{i}$ associated with $\mathrm{Ca}^{2+}$ responses that triggers a Ca ${ }^{2+}$ dependent $5-\mathrm{HT}$ secretion in EC cells. In addition, patch-clamp studies revealed that UTP increases $\mathrm{I}_{\mathrm{Ca}}$ currents by activation of VOCCs via P2Y $\mathrm{Y}_{4}$; $\mathrm{P}_{2} \mathrm{Y}_{6}$ is presumed to have an inhibitory effect on VOCCs. As well, activation of $\mathrm{P}_{2} \mathrm{Y}_{4}$ causes a $\mathrm{V}_{\mathrm{m}}$ depolarization that was independent of VOCC activation, but was eliminated by the $\mathrm{K}_{\mathrm{v}}$ 7.1/7.2/7.3 channel inhibitor XE-991. We hypothesize that UTP depolarizes the cell by reducing a potassium conductance (not yet identified), which occurs as a consequence of depleting PIP2 from the membrane by its conversion to IP3 after PLC activation. $\mathrm{V}_{\mathrm{m}}$ depolarization seems not linked to $\mathrm{Ca}^{2+}$ dependent 5-HT release but it may play a role in the fine tuning of the pathway. In a parallel way UTP reduced a component of $I_{K}$ currents that was insensitive to XE-991, and the identity of the $\mathrm{K}_{v}$ channel remains unknown. This response does not explain the effect of UTP on $V_{m}$ depolarization. A rise in intracellular free Ca ${ }^{2+}$ is required for $5-\mathrm{HT}$ release. However, zero $\mathrm{Ca}^{2+}$ buffer augments both $\left[\mathrm{Ca}^{2+}\right]_{i}$ inside the cell and $5-\mathrm{HT}$ release. The mechanism for this paradoxical effect of $\mathrm{Ca}^{2+}$ influx is unknown. Concepts are based on data from a BON cell model of human EC cells. Isolated EC cells from human intestinal surgical specimens were used to confirm effect of UTP on 5-HT release and expression of $\mathrm{P}_{2} \mathrm{Y}_{4}$ and $\mathrm{P} 2 \mathrm{Y}_{6}$ receptors.

depolarization, since zero $\mathrm{Ca}^{2+}$ buffer or nicardipine did not influence the response. The identity of the VOCC activated by UTP and its role in the regulation of 5-HT release remains unknown.

\section{Significance of Findings in BON and Translatability to EC Cells}

As discussed in a recent review on sensory signaling in EC cells on 5-HT release, much of our knowledge and concepts of sensory signaling in EC cells (both mechanical and chemical signaling) comes from the human BON cell model of EC, although more recent work has included other cell lines, native EC cells and intact mucosa (Liñán-Rico et al., 2016). The pitfalls and use of BON or other cell lines, and human EC cells are described in detail in the review. Notably, some of the earlier publications on BON provided fundamental knowledge about mechanisms regulating EC cell function, i.e., mechanosensation (Kim et al., 2001a), glucose stimulation of 5-HT release (Kim et al., 2001b), purinergic autocrine regulation of 5-HT release in EC cells (Christofi et al., 2004a), and more recent studies on purinergic $\mathrm{P}_{2} \mathrm{Y}_{1}, \mathrm{P}_{2} \mathrm{X}_{3}$ and $\mathrm{P} 2 \mathrm{Y}_{12}$ regulation of 5-HT release, also showing that $\mathrm{P} 2 \mathrm{X}_{3}$ expression in native $\mathrm{EC}$ cells is severely down regulated in ulcerative colitis (Liñán-Rico et al., 2013). Data from BON on purinergic receptors are translatable to native EC cells (Chin et al., 2012; Liñán-Rico et al., 2013), and although our current study focused primarily on BON as a model of EC cells, we were able to confirm expression of the key receptor(s) in native EC cells and show that activation of uridine phosphate receptors by UTP stimulates 5 -HT release. Furthermore, an unexpected finding worth further investigation is that calcium influx provides an inhibitory influence on 5-HT release. The data provide a basis for more complex and challenging experiments in native EC cells isolated from surgical specimens (Raghupathi et al., 2013), and selected studies on UTP regulation of 5-HT release in intact human surgical tissues with agonists and antagonists to confirm findings in a more physiologically intact environment. 
Our working model of UTP signaling in EC cells is depicted in Figure 14. UTP elicits calcium oscillations via a $\mathrm{G}_{\mathrm{q}} / \mathrm{PLC} / \mathrm{IP} 3 / \mathrm{IP} 3 \mathrm{R} / \mathrm{SERCA} \mathrm{Ca}^{2+}$ pump signaling mechanism to stimulate 5-HT release through primarily a $\mathrm{P} 2 \mathrm{Y}_{4} \mathrm{R}$ mechanism, although the $\mathrm{P}_{2} \mathrm{Y}_{6} \mathrm{R}$ may contribute. Different combinations of receptors may be expressed in the same cells, and subsets of EC cells can be distinguished by expressing functional $\mathrm{P} 2 \mathrm{Y}_{4}, \mathrm{P} 2 \mathrm{Y}_{6}$, $\mathrm{P}_{2} \mathrm{Y}_{2}, \mathrm{P}_{2} \mathrm{Y}_{4}$ and $\mathrm{P} 2 \mathrm{Y}_{6}$ or other receptors. Activation of $\mathrm{P} 2 \mathrm{Y}_{4} \mathrm{R}$ causes $\mathrm{V}_{\mathrm{m}}$ depolarization dependent on $\mathrm{I}_{\mathrm{K}}$ currents (not yet identified) and independent of VOCC/ $/ \mathrm{I}_{\mathrm{ca}}, \mathrm{I}_{\mathrm{A}}$ or $\mathrm{Ca}^{2+}$ oscillations. We hypothesize that UTP depolarizes the cell by reducing a potassium conductance through $\mathrm{K}^{+}$channels, which occurs as a consequence of depleting PIP2 from the membrane by its conversion to $\mathrm{IP}_{3}$ after PLC activation. $\mathrm{V}_{\mathrm{m}}$ depolarization seems not linked to $\mathrm{Ca}^{2+}$ dependent 5-HT release but it may play a role in the fine tuning of the pathway. In a parallel way, UTP reduced a component of $\mathrm{I}_{\mathrm{K}}$ currents that was insensitive to XE-991, and the identity of the specific $K_{V}$ channel remains unknown. This effect of UTP on $K_{v}$ channels does not explain its effect on $\mathrm{V}_{\mathrm{m}}$ depolarization. UTP stimulates $\mathrm{I}_{\mathrm{Ca}}$ currents by activating VOCCs not involved in $\mathrm{V}_{\mathrm{m}}$ depolarization. A rise in intracellular free $\mathrm{Ca}^{2+}$ is required for 5-HT release, although $\mathrm{Ca}^{2+}$ influx may attenuate 5 -HT release. $\mathrm{Ca}^{2+}$ influx through a $\mathrm{La}^{3+}-$ insensitive mechanism (since $\mathrm{La}^{3+}$ blocks $\mathrm{Ca}^{2+}$ responses) seems to provide ongoing inhibitory modulation of $5-\mathrm{HT}$ release. It is not known whether all these mechanisms are linked to 5-HT release, and if they operate in normal EC cells. Monophasic and oscillatory $\mathrm{Ca}^{2+}$ responses may represent distinct receptors (or mechanisms).

Overall, UTP signaling is an important mechanism in regulation of 5-HT release from human EC cells, worth exploring in GI diseases or disorders associated with abnormal 5-HT signaling.

\section{AUTHOR CONTRIBUTIONS}

AL-R, study design, experiments, data analysis, interpretation and manuscript writing; contributed to $\mathrm{Ca}^{2+}$ imaging and molecular signaling studies, 5-HT release studies. FO-C, Study design, experiments, data analysis, interpretation and manuscript writing; contributed to patch-clamp and molecular signaling studies. AZ-A, Study design, experiments, data analysis, interpretation and manuscript writing; contributed to $\mathrm{Ca}^{2+}$ imaging studies and concentration-response curve for

\section{REFERENCES}

Abbracchio, M. P., Burnstock, G., Boeynaems, J. M., Barnard, E. A., Boyer, J. L., Kennedy, C., et al. (2006). International Union of Pharmacology LVIII: update on the P2Y G protein-coupled nucleotide receptors: from molecular mechanisms and pathophysiology to therapy. Pharmacol. Rev. 58, 281-341. doi: 10.1124/pr.58.3.3

Alkhani, H., Ase, A. R., Grant, R., O’Donnell, D., Groschner, K., and Séguéla, P. (2014). Contribution of TRPC3 to store-operated calcium entry and inflammatory transductions in primary nociceptors. Mol. Pain 10, 43. doi: 10.1186/1744-8069-10-43
UTP. MA, Contributed to molecular signaling studies and performed the western blot analyses; contributed to the results and discussion of the manuscript. JE, As an undergraduate student research assistant, he participated in all studies and di the immunohistochemical studies for $\mathrm{P}_{4}, 5-\mathrm{HT}, \mathrm{TPH} 1$ in BON or hEC cells. AH, Co-Investigator on NIH studies on purinergic regulation of EC cell release of 5-HT; GI Surgeon who was responsible for successful procurement of viable gut surgical specimens for isolating hEC cells for 5-HT release and IHC studies; contributed to study design, data analysis, and manuscript submission. ET, Contributed to qPCR analyses of $\mathrm{P}_{2} \mathrm{Y}_{4}$ and $\mathrm{P}_{2} \mathrm{Y}_{6}$ receptors, data analysis, interpretation and manuscript preparation. IG, Contributed to 5-HT release studies, IHC studies, data analysis, interpretation and manuscript preparation and all figures and illustrations. SB, co-mentor to AZ-A a postdoctoral fellow in the lab. Supported the overall study design, interpretation of data, and manuscript writing and submission. FC, Principal Investigator of the NIH funded study, and was responsible for the overall study design, conduct of the study, data analysis, interpretation, and manuscript writing and submission.

\section{FUNDING}

This work was supported by the National Institute of Diabetes and Digestive and Kidney Disease [Grant DK093499]; the National Center for Research Resources [Grant S10RR11434]; and strategic initiative funds from the Department of Anesthesiology and College of Medicine at OSU to FC.

\section{ACKNOWLEDGMENT}

Authors want to thank the clinical research coordinators participating in the consent, and procurement of human surgical tissue for the isolation of human EC cells for 5-HT release.

\section{SUPPLEMENTARY MATERIAL}

The Supplementary Material for this article can be found online at: http://journal.frontiersin.org/article/10.3389/fphar. 2017.00429/full\#supplementary-material

Bilbao, P. S., Katz, S., and Boland, R. (2012). Interaction of purinergic receptors with GPCRs, ion channels, tyrosine kinase and steroid hormone receptors orchestrates cell function. Purinergic Signal. 8, 91-103. doi: 10.1007/s11302011-9260-9

Block, B. M., Stacey, W. C., and Jones, S. W. (1998). Surface charge and lanthanum block of calcium current in bullfrog sympathetic neurons. Biophys. J. 74, 2278-2284. doi: 10.1016/S0006-3495(98)77937-8

Brinson, A. E., and Harden, T. K. (2001). Differential regulation of the uridine nucleotide-activated P2Y4 and P2Y6 receptors. SER-333 and SER-334 in the carboxyl terminus are involved in agonist-dependent phosphorylation desensitization and internalization of the P2Y4 
receptor. J. Biol. Chem. 276, 11939-11948. doi: 10.1074/jbc.M0099 09200

Brown, D. A., and Passmore, G. M. (2009). Neural KCNQ (kv7) channels. Br. J. Pharmacol. 156, 1185-1195. doi: 10.1111/j.1476-5381.2009.00111.x

Brunschweiger, A., and Müller, C. E. (2006). P2 receptors activated by uracil nucleotides-an update. Curr. Med. Chem. 13, 289-312. doi: 10.2174/ 092986706775476052

Burnstock, G. (2008). The journey to establish purinergic signaling in the gut. Neurogastroenterol. Motil. 20, 8-19. doi: 10.1111/j.1365-2982.2008.01107.x

Chin, A., Svejda, B., Gustafsson, B. I., Granlund, A. B., Sandvik, A. K., Timberlake, A., et al. (2012). The role of mechanical forces and adenosine in the regulation of intestinal enterochromaffin cell serotonin secretion. Am. J. Physiol. Gastrointest. Liver Physiol. 302, G397-G405. doi: 10.1152/ajpgi.00087.2011

Christofi, F. L. (2008). Purinergic receptors and gastrointestinal secretomotor function. Purinergic Signal. 4, 213-236. doi: 10.1007/s11302-008-9104-4

Christofi, F. L., Kim, M., Wunderlich, J. E., Xue, J., Suntres, Z., Cardounel, A., et al. (2004a). Endogenous adenosine differentially modulates 5-Hydroxytryptamine release from a human enterochromaffin cell model. Gastroenterology 127, 188-202.

Christofi, F. L., Wunderlich, J., Yu, J. G., Wang, Y. Z., Xue, J., Guzman, J., et al. (2004b). Mechanically evoked reflex electrogenic chloride secretion in rat distal colon is triggered by endogenous nucleotides acting at P2Y1, P2Y2, and P2Y4 receptors. J. Comp. Neurol. 469, 16-36. doi: 10.1002/cne.10961

Communi, D., Robaye, B., and Boeynaems, J. M. (1999). Pharmacological characterization of the human P2Y11 receptor. Br. J. Pharmacol. 128, 1199-1206. doi: 10.1038/sj.bjp.0702909

Cooke, H. J., and Christofi, F. L. (2006). Physiology of the Gastrointestinal Tract, Fourth Edn. New York, NY: Academic Press.

Cooke, H. J., Wunderlich, J., and Christofi, F. L. (2003). "The Force Be with You”: ATP in the gut mechanosensory transduction. News Physiol. Sci. 18, 43-49. doi: 10.1152/nips.01411.2002

Cooke, H. J., Xue, J., Yu, J. G., Wunderlich, J., Wang, Y. Z., Guzman, J., et al. (2004). Mechanical stimulation releases nucleotides that activate $\mathrm{P} 2 \mathrm{Y} 1$ receptors to trigger neural reflex chloride secretion in guinea pig distal colon. J. Comp. Neurol. 469, 1-15. doi: 10.1002/cne.10960

Crowell, M. D. (2004). Role of serotonin in the pathophysiology of the irritable bowel syndrome. Br. J. Pharmacol. 141, 1285-1293. doi: 10.1038/sj.bjp.0705762

D’Ambrosi, N., Iafrate, M., Saba, E., Rosa, P., and Volonté, C. (2007). Comparative analysis of P2Y4 and P2Y 6 receptor architecture in native and transfected neuronal systems. Biochim. Biophys. Acta 1768, 1592-1599. doi: 10.1016/j. bbamem.2007.03.020

D’Ambrosi, N., Iafrate, M., Vacca, F., Amadio, S., Tozzi, A., Mercuri, N. B., et al. (2006). The P2Y4 receptor forms homo-oligomeric complexes in several CNS and PNS neuronal cells. Purinergic Signal. 2, 575-582. doi: 10.1007/s11302-0069014-2

Dammen, R., Haugen, M., Svejda, B., Alaimo, D., Brenna, O., Pfragner, R., et al. (2013). The stimulatory adenosine receptor ADORA2B regulates serotonin (5-HT) synthesis and release in oxygen-depleted EC cells in inflammatory bowel disease. PLoS ONE 8:e62607. doi: 10.1371/journal.pone.0062607

Falkenburger, B. H., Dickson, E. J., and Hille, B. (2013). Quantitative properties and receptor reserve of the DAG and PKC branch of G(q)-coupled receptor signaling. J. Gen. Physiol. 141, 537-555. doi: 10.1085/jgp.2012 10887

Falkenburger, B. H., Jensen, J. B., and Hille, B. (2010). Kinetics of PIP2 metabolism and KCNQ2/3 channel regulation studied with a voltage-sensitive phosphatase in living cells. J. Gen. Physiol. 135, 99-114. doi: 10.1085/jgp.200910345

Galligan, J. J. (2004). 5-hydroxytryptamine, ulcerative colitis, and irritable bowel syndrome: molecular connections. Gastroenterology 126, 1897-1899. doi: 10.1053/j.gastro.2004.04.028

Germano, P. M., Lieu, S. N., Xue, J., Cooke, H. J., Christofi, F. L., Lu, Y., et al. (2009). PACAP induces signaling and stimulation of 5-hydroxytryptamine release and growth in neuroendocrine tumor cells. J. Mol. Neurosci. 39, 391-401. doi: 10.1007/s12031-009-9283-7

Gershon, M. D. (2004). Review article: serotonin receptors and transporters - roles in normal and abnormal gastrointestinal motility. Aliment. Pharmacol. Ther. 20(Suppl. 7), 3-14. doi: 10.1111/j.1365-2036.2004.02180.x

Harper, J. L., Camerini-Otero, C. S., Li, A. H., Kim, S. A., Jacobson, K. A., and Daly, J. W. (2003). Dihydropyridines as inhibitors of capacitative calcium entry in leukemic HL-60 cells. Biochem. Pharmacol. 65, 329-338. doi: 10.1016/S00062952(02)01488-0

Hirasawa, T., Kotani, S., Suzuki, T., Sato, K., Sakakibara, M., and Tokimasa, T. (2000). Effects of lanthanides on voltage-dependent potassium currents in bullfrog sympathetic neurons. Neurosci. Lett. 290, 97-100. doi: 10.1016/S03043940(00)01335-5

Hughes, S., Marsh, S. J., Tinker, A., and Brown, D. A. (2007). PIP2-dependent inhibition of M-type (Kv7. 2/7.3) potassium channels: direct on-line assessment of PIP2 depletion by Gq-coupled receptors in single living neurons. Pflugers Arch. 455, 115-124. doi: 10.1007/s00424-007-0259-6

Jacobson, J., Ivanov, A. A., Castro, S., Harden, K., and Ko, H. (2009). Development of selective agonists and antagonists for P2Y receptors. Purinergic Signal. 5, 75-89. doi: 10.1007/s11302-008-9106-2

Jacobson, J., and Linden, J. (2011). Pharmacology of Purines and Pyrimidine Receptors. San Diego, CA: Academic Press.

Kaznacheyeva, E., Zubov, A., Gusev, K., Bezprozvanny, I., and Mozhayeva, G. N. (2001). Activation of calcium entry in human carcinoma A431 cells by store depletion and phospholipase C- dependent mechanisms converge on ICRAClike calcium channels. Proc. Natl. Acad. Sci. U.S.A. 98, 148-153. doi: 10.1073/ pnas.98.1.148

Kellum, J. M., Albuquerque, F. C., Stoner, M. C., and Harris, R. P. (1999). Stroking human jejunal mucosa induces 5 -HT release and $\mathrm{Cl}$ - secretion via afferent neurons and 5-HT4 receptors. Am. J. Physiol. 277, G515-G520.

Kennedy, C., Qi, A. D., Herold, C. L., Harden, T. K., and Nicholas, R. A. (2000). ATP, an agonist at the rat $\mathrm{P} 2 \mathrm{Y}(4)$ receptor, is an antagonist at the human $\mathrm{P} 2 \mathrm{Y}(4)$ receptor. Mol. Pharmacol. 57, 926-931.

Khakh, B. S., Burnstock, G., Kennedy, C., King, B. F., North, R. A., Séguéla, P., et al. (2001). International union of pharmacology. XXIV. Current status of the nomenclature and properties of $\mathrm{P} 2 \mathrm{X}$ receptors and their subunits. Pharmacol. Rev. 53, 107-118.

Kim, M., Christofi, F. L., Xue, J., Robinson, J. M., and Cooke, H. J. (2007). Mechanically evoked 5-hydroxytryptamine release is mediated by caveolinassociated cholesterol rich membrane domains. Neurogastroenterol. Motil. 19, 309-317. doi: 10.1111/j.1365-2982.2007.00912.x

Kim, M., Cooke, H. J., Javed, N. H., Carey, H. V., Christofi, F., and Raybould, H. E. (2001a). D- glucose releases 5-hydroxytryptamine from human BON cells as a model of enterochromaffin cells. Gastroenterology 121, 1400-1406.

Kim, M., Javed, N. H., Yu, J. G., Christofi, F. L., and Cook, H. J. (2001b). Mechanical stimulation activates $\mathrm{G} \alpha \mathrm{q}$ signaling pathways and 5-hydroxytryptamine release from human carcinoid BON cells. J. Clin. Invest. 108, 1051-1059. doi: 10.1172/ JCI12467

Kordasti, S., Sjovall, H., Lundgren, O., and Svensson, L. (2004). Serotonin and vasoactive intestinal peptide antagonists attenuate rotavirus diarrhoea. Gut 53, 952-957. doi: 10.1136/gut.2003.033563

Kügelgen, I. V. (2006). Pharmacological profiles of cloned mammalian P2Yreceptor subtypes. Pharmacol. Ther. 110, 415-432. doi: 10.1016/j.pharmthera. 2005.08.014

Kügelgen, I. V., and Bonn, D. (2008). Pharmacology of mammalian P2X-and P2Y-receptors. Biotrend Rev. 3, 1-12.

Lazarowski, E. R., and Harden, T. K. (1999). Quantitation of extracellular UTP using a sensitive enzymatic assay. Br. J. Pharmacol. 127, 1272-1278. doi: 10. 1038/sj.bjp.0702654

Lazarowski, E. R., Homolya, L., Boucher, R. C., and Harden, T. K. (1997). Direct demonstration of mechanically induced release of cellular UTP and its implication for uridine nucleotide receptor activation. J. Biol. Chem. 272, 24348-24354. doi: 10.1074/jbc.272.39.24348

Liñán-Rico, A., Ochoa-Cortes, F., Beyder, A., Soghomonyan, S., Zuleta-Alarcon, A., Coppola, V., et al. (2016). Mechanosensory signaling in enterochromaffin cells and 5-HT release: potential implications for gut inflammation. Front. Neurosci. 10:564. doi: 10.3389/fnins.2016.00564

Liñán-Rico, A., Wunderlich, J. E., Enneking, J. T., Tso, D. R., Grants, I., Williams, K. C., et al. (2015). Neuropharmacology of purinergic receptors in human submucous plexus: involvement of P2X1, P2X2, P2X3 channels, P2Y and A3 metabotropic receptors in neurotransmission. Neuropharmacology 95, 83-99. doi: 10.1016/j.neuropharm.2015.02.014

Liñán-Rico, A., Wunderlich, J. E., Grants, I. S., Frankel, W. L., Xue, J., Williams, K. C., et al. (2013). Purinergic autocrine regulation of mechanosensitivity and serotonin release in a human EC model: ATP-gated P2X3 channels in EC 
are downregulated in ulcerative colitis. Inflamm. Bowel Dis. 19, 2366-2379. doi: 10.1097/MIB.0b013e31829ecf4d

Lomax, R. B., Gallego, S., Novalbos, J., García, A. G., and Warhurst, G. (1999). L-type calcium channels in enterochromaffin cells from guinea pig and human duodenal crypts: an in situ study. Gastroenterology 117, 1363-1369. doi: 10.1016/S0016-5085(99)70286-6

Mani, B. K., Brueggemann, L. I., and Byron, K. (2011). Reply to Chadha et al. Br. J. Pharmacol. 164, 252-253. doi: 10.1111/j.1476-5381.2011.01457.x

Manocha, M., and Khan, W. I. (2012). Serotonin and GI Disorders: an update on clinical and experimental studies. Clin. Transl. Gastroenterol. 3, e13. doi: $10.1038 / \operatorname{ctg} .2012 .8$

Mawe, G. M., and Hoffman, J. M. (2013). Serotonin signalling in the gut-functions, dysfunctions and therapeutic targets. Nat. Rev. Gastroenterol. Hepatol. 10, 473-486. doi: 10.1038/nrgastro.2013.105

Meis, S., Hamacher, A., Hongwiset, D., Marzian, C., Wiese, M., Eckstein, N., et al. (2010). NF546 [4, 4'-(carbonylbis (imino-3, 1-phenylene-carbonylimino-3, 1-(4-methyl-phenylene)-carbonylimino))-bis (1, 3-xylene- $\alpha, \alpha$ '-diphosphonic acid) tetrasodium salt] is a non-nucleotide P2Y11 agonist and stimulates release of interleukin-8 from human monocyte-derived dendritic cells. J. Pharmacol. Exp. Ther. 332, 238-247. doi: 10.1124/jpet.109.157750

Mergler, S., Skrzypski, M., Sassek, M., Pietrzak, P., Pucci, C., Wiedenmann, B., et al. (2012). Thermo-sensitive transient receptor potential vanilloid channel1 regulates intracellular calcium and triggers chromogranin A secretion in pancreatic neuroendocrine BON-1 tumor cells. Cell. Signal. 24, 233-246. doi: 10.1016/j.cellsig.2011.09.005

Morrow, G. B., Nicholas, R. A., and Kennedy, C. (2014). UTP is not a biased agonist at human P2Y11 receptors. Purinergic Signal. 10, 581-585. doi: 10.1007/s11302014-9418-3

Nikodijevic, B., Sei, Y., Shin, Y., and Daly, J. W. (1994). Effects of ATP and UTP in pheochromocytoma PC12 cells: evidence for the presence of three P2 receptors, only one of which subserves stimulation of norepinephrine release. Cell Mol. Neurobiol. 14, 27-47. doi: 10.1007/BF02088587

Ochoa-Cortes, F., Liñán-Rico, A., Jacobson, K. A., and Christofi, F. L. (2014). Potential for developing purinergic drugs for gastrointestinal diseases. Inflamm. Bowel Dis. 20, 1259-1287. doi: 10.1097/MIB.0000000000000047

O’Hara, J. R., Ho, W., Linden, D. R., Mawe, G. M., and Sharkey, K. A. (2004). Enteroendocrine cells and 5-HT availability are altered in mucosa of guinea pigs with TNBS ileitis. Am. J. Physiol. Gastrointest. Liver Physiol. 287, G998-G1007. doi: 10.1152/ajpgi.00090.2004

Pena, F., and Ordaz, B. (2008). Non-selective cation channel blockers: potential use in nervous system basic research and therapeutics. Mini Rev. Med. Chem. 8, 812-819. doi: 10.2174/138955708784912166

Raghupathi, R., Duffield, M. D., Zelkas, L., Meedeniya, A., Brookes, S. J., Sia, T. C., et al. (2013). Identification of unique release kinetics of serotonin from guinea-pig and human enterochromaffin cells. J. Physiol. 591, 5959-5975. doi: 10.1113/jphysiol.2013.259796

Raybould, H. E., Cooke, H. J., and Christofi, F. L. (2004). Sensory mechanisms: transmitters, modulators and reflexes. Neurogastroenterol. Motil. 16, 60-63. doi: 10.1111/j.1743-3150.2004.00477.x

Schroeder, B. C., Waldegger, S., Fehr, S., Bleich, M., Warth, R., Greger, R., et al. (2000). A constitutively open potassium channel formed by KCNQ1 and KCNE3. Nature 403, 196-199. doi: 10.1038/35003200

Spencer, N. J., Nicholas, S. J., Robinson, L., Kyloh, M., Flack, N., Brookes, S. J., et al. (2011). Mechanisms underlying distension-evoked peristalsis in guinea pig distal colon: is there a role for enterochromaffin cells? Am. J. Physiol. Gastrointest. Liver Physiol. 301, G519-G527. doi: 10.1152/ajpgi.00101. 2011

Toullec, D., Pianetti, P., Coste, H., Bellevergue, P., Grand-Perret, T., Ajakane, M., et al. (1991). The bisindolylmaleimide GF 109203X is a potent and selective inhibitor of protein kinase C. J. Biol. Chem. 266, 15771-15781.

Tuluc, F., Bredetean, O., Brailoiu, E., Meshki, J., Garcia, A., Dun, N. J., et al. (2005). The priming effect of extracellular UTP on human neutrophils: role of calcium released from thapsigargin-sensitive intracellular stores. Purinergic Signal. 1, 359-368. doi: 10.1007/s11302-005-0039-8

Ullrich, S., Su, J., Ranta, F., Wittekindt, O. H., Ris, F., Rösler, M., et al. (2005). Effects of IKs channel inhibitors in insulin-secreting INS-1 cells. Pflügers Archiv. 451, 428-436. doi: 10.1007/s00424-005-1479-2

Welsh, D. G., and Brayden, J. E. (2001). Mechanisms of coronary artery depolarization by uridine triphosphate. Am. J. Physiol. Heart Circ. Physiol. 280, H2545-H2553.

Wihlborg, A. K., Malmsjo, M., Eyjolfsson, A., Gustafsson, R., Jacobson, K., and Erlinge, D. (2003). Extracellular nucleotides induce vasodilatation in human arteries via prostaglandins, nitric oxide and endothelium-derived hyperpolarizing factor. Br. J. Pharmacol. 138, 1451-1458. doi: 10.1038/sj.bjp. 0705186

Wladyka, C. L., and Kunze, D. L. (2006). KCNQ/M-currents contribute to the resting membrane potential in rat visceral sensory neurons. J. Physiol. 575, 175-189. doi: 10.1113/jphysiol.2006.113308

Wunderlich, J. E., Needleman, B. J., Chen, Z., Yu, J. G., Wang, Y., Grants, I., et al. (2008). Dual purinergic synaptic transmission in the human enteric nervous system. Am. J. Physiol. Gastrointest. Liver Physiol. 294, G554-G566. doi: 10.1152/ajpgi.00500.2007

Yadav, V. K., Balaji, S., Suresh, P. S., Liu, X. S., Lu, X., Li, Z., et al. (2010). Pharmacological inhibition of gut-derived serotonin synthesis is a potential bone anabolic treatment for osteoporosis. Nat. Med. 16, 308-312. doi: 10.1038/ nm.2098

Yamagata, K., Senokuchi, T., Lu, M., Takemoto, M., Karim, M. F., Go, C., et al. (2011). Voltage-gated K channel KCNQ1 regulates insulin secretion in MIN6 $\beta$-cell line. Biochem. Biophys. Res. Commun. 407, 620-625. doi: 10.1016/j.bbrc. 2011.03.083

Yeung, S. Y. M., and Greenwood, I. A. (2005). Electrophysiological and functional effects of the KCNQ channel blocker XE991 on murine portal vein smooth muscle cells. Br. J. Pharmacol. 146, 585-595. doi: 10.1038/sj.bjp.0706342

Zhang, F. L., Luo, L., Gustafson, E., Palmer, K., Qiao, X., Fan, X., et al. (2002). P2Y13: identification and characterization of a novel Gai-coupled ADP receptor from human and mouse. J. Pharmacol. Exp. Ther. 301, 705-713. doi: 10.1124/jpet.301.2.705

Zhang, H., Craciun, L. C., Mirshahi, T., Rohács, T., Lopes, C. M., Jin, T., et al. (2003). PIP 2 activates KCNQ channels, and its hydrolysis underlies receptormediated inhibition of M currents. Neuron 37, 963-975. doi: 10.1016/S08966273(03)00125-9

Zhong, X. Z., Harhun, M. I., Olesen, S. P., Ohya, S., Moffatt, J. D., Cole, W. C., et al. (2010). Participation of KCNQ (Kv7) potassium channels in myogenic control of cerebral arterial diameter. J. Physiol. 588, 3277-3293. doi: 10.1113/jphysiol. 2010.192823

Conflict of Interest Statement: The authors declare that the research was conducted in the absence of any commercial or financial relationships that could be construed as a potential conflict of interest.

Copyright (c) 2017 Liñán-Rico, Ochoa-Cortes, Zuleta-Alarcon, Alhaj, Tili, Enneking, Harzman, Grants, Bergese and Christofi. This is an open-access article distributed under the terms of the Creative Commons Attribution License (CC BY). The use, distribution or reproduction in other forums is permitted, provided the original author(s) or licensor are credited and that the original publication in this journal is cited, in accordance with accepted academic practice. No use, distribution or reproduction is permitted which does not comply with these terms. 